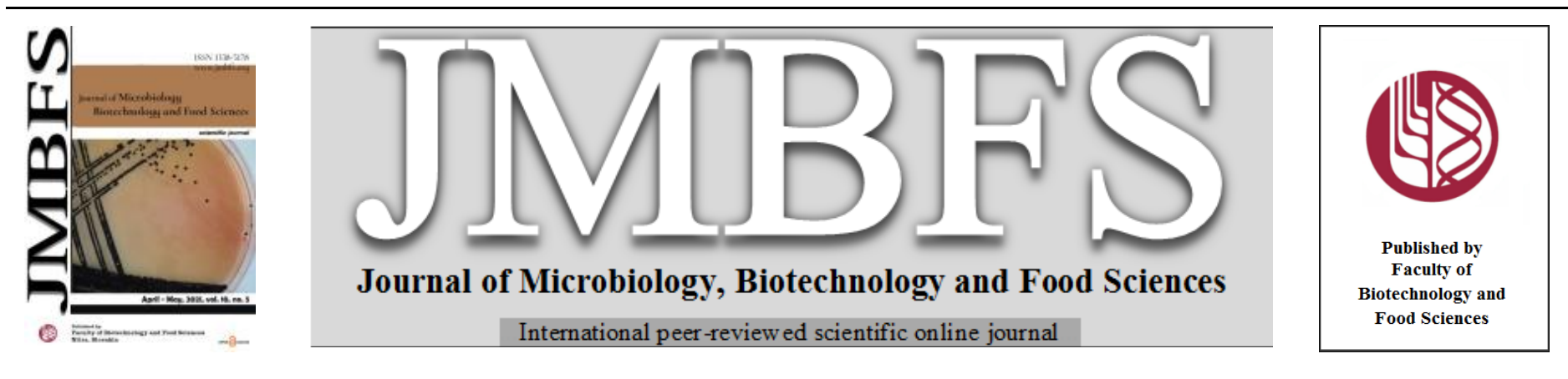

\title{
SELECTION OF TOLERANT WHEAT VARIETIES DURING THE GERMINATION PHASE
}

\author{
Fatine Mouhssine ${ }^{*}$, Sara Ech-Cheddadi ${ }^{l}$, Moussa Ouhaddach ${ }^{1}$,Younes El Goumi ${ }^{2}$, Houda El yacoubi ${ }^{l}$, Atmane Rochdi ${ }^{l}$ \\ $\operatorname{Address}(e s):$ \\ ${ }^{1}$ Laboratory of Agro-Physiology, Biotechnology, Environment \& Quality. Faculty of Sciences, Ibn Tofail University; BP133- Kénitra 14000, Morocco. \\ ${ }^{2}$ National Agency for Medicinal and Aromatic Plants, Phyto-Biotechnology Laboratory Taounate-Morocco.
}

*Corresponding author: Fatinemh@ gmail.com

https://doi.org/10.15414/jmbfs.2341

\section{ARTICLE INFO}

Received 15. 11. 2019

Revised 8. 12. 2020

Accepted 15. 12. 2020

Published 1. 4. 2021

Regular article

OPEN $\partial_{\text {ACCESS }}$

\begin{abstract}
In Morocco, wheat is an indispensable and important crop for the population. Its production in areas affected by salinity is a major problem. The salinity-tolerant variety factor is one of the ways to ensure good productivity. Germination is considered a critical step in the plant's development cycle. Consequently, this study aimed to screen the tolerance to salinity of five varieties of wheat at the germination stage. The experiment was carried out under laboratory conditions, using five concentrations of $\mathrm{NaCl} 0,3,6,9$, and $12 \mathrm{~g} / \mathrm{L}$. Several parameters were used: the germination rate, the corrected germination, the reduction percentage in germination, the final percentage of germination, the mean daily germination, the germination index, the vigor index of germination, the germination rate index, the velocity coefficient, the average time of germination, the length of coleoptiles and roots. Intraspecific variability of wheat toward salinity was relatively large. The daily germination rate, the final germination, the reduction percentage in germination, the germination rate index, and the mean daily germination proved to be the most appropriate criteria to study the salinity effect on seed germination. Also, an equal hierarchy of sensitivity/tolerance levels during the subsequent development of the coleoptiles and the roots has been adversely affected by increasing salinity. All these parameters describing the germination wheat seeds showed that Rajae variety performs better (relatively tolerant) while; Radia and Kanz varieties are the most affected by salt stress. The results showed that the salt reduces germination by delaying its speed except for Rajae and Amal.
\end{abstract}

\section{INTRODUCTION}

Salinity is a complex genetic phenomenon (Colmer et al., 2005). It is foremost one of the environmental factors that affect agricultural production in arid and semi-arid regions, in both pluvial agriculture and complementary irrigation (Benderradji et $\boldsymbol{a l}$., 2010). Parallel to other countries with hot and dry climates, Morocco is no exception to this plague which, began to take alarming dimensions in the majority of the irrigated perimeters, particularly, in the arid and preSaharan regions, consequently, reducing arable lands and threatening the kingdom's food security. Tolerance to the presence of salts such as sodium chloride is, therefore, a quality largely sought in plants of agronomic interest to broaden their cultivation in these regions (Ben khaled et al., 2007; Mrani alaoui et $a l$., 2013).

Wheat (Triticum aestivum L.) is considered a major cereal crop and staple food worldwide (Bhutto et al., 2018). In Morocco, wheat occupies an important part of agricultural production, covering an area of 2.85 million hectares, of which 0.93 million hectares are planted with durum wheat and 1.92 million hectares with common wheat (DPAE 2008, Nassif et al., 2012). In recent years, its production in areas affected by salinity has become a major problem. Salt stress has a negative impact on plant development starting from seed germination to subsequent growth stages. Diverse studies have indicated that plants exhibit multiple morpho-physiological, and biochemical changes (depending on the severity and duration of the stress) such as leaf expansion decrease, stomatal closure, inhibition of photosynthesis, biomass reduction, accumulation of organic solutes such as sugars, amino acids, proteins, and many other compounds to fight the harmful effects of Na+ and Cl- (Koutoua et al., 2012; Zhang and Shi, 2013; Ouhaddach et al., 2016).

Currently, the identification of genotypes of new salt-tolerant crop varieties that may outperform current varieties is a critical requirement as well for agricultural biotechnology as for the future of agriculture in arid and semi-arid regions (Kumar et al., 2019; Acosta-motos et al., 2020; Srivastava, 2020). Recent research progress, has thus, focused on the development of programs for the selection of tolerant genotypes and varieties to improve both crop tolerance and yield in salt-affected soils (Abiala et al., 2018; Mbarki et al., 2018; Ismail et al., 2019; Safdar et al., 2019; Acosta-motos et al ., 2020). Nevertheless, the development of salt-tolerant plants is still at an early step which, should become more effective as we acquire a better understanding of the mechanism of tolerance to salt (Ismail et al., 2019).

Plants differ significantly in their sensitivity to salt stress depending on the concentration, the duration of exposure and the stage of development (Safdar et al., 2019; Natasha, 2019; Mirza et al., 2019). Germination is considered one of the critical stages because it has a major role in determining final plant density. Therefore, salt tolerance is particularly important during germination where high soil salinity near the soil surface can inhibit growth (Jorenush and Rajabi, 2015).

The objective of our study was to study the adverse effect of salinity on certain parameters describing the progression of seeds' germination of five varieties of wheat. Moreover, since seeds germination begins with their imbibition, it seems logical to incorporate the salt $(\mathrm{NaCl})$ during the disinfection steps by using the same concentrations used later in the germination test.

\section{MATERIAL AND METHODS}

\section{Plant Material}

The essays were carried out under laboratory conditions on seeds wheat (Triticum aestivum L.). Five varieties (Amal, Arrehane, Kanz, Radia, and Rajae) provided by ONSSA (National Office for Product Safety food) were used in the experimentation. These varieties are listed in the catalog of SONACOS "National Seed Marketing Corporation - Morocco" (Tab 1): 
Table1 Principal characteristics of five wheat varieties grown in Morocco

\begin{tabular}{|c|c|c|}
\hline Variety & Characteristics & Origin and registration date \\
\hline ARREHANE & $\begin{array}{l}\text { - Height of the plant: } 75 \text { to } 100 \mathrm{~cm} \text {, depending on conditions ; } \\
\text { - Cycle at maturity: Early; } \\
\text { - Arrehane is recommended for borage and irrigated zones. It is suitable for the late seedling } \\
\text { in both irrigated and borage regions. }\end{array}$ & INRA-Morocco (1996) \\
\hline RADIA & $\begin{array}{l}\text { - Plant height : Average; } \\
\text { - Ripening cycle: Semi-early } \\
\text { - It is a variety with high potential for irrigated and well-watered areas in the north of the } \\
\text { country (Morocco). }\end{array}$ & F. Desprez- France (2006) \\
\hline AMAL & $\begin{array}{l}\text { - Height of the plant: } 85 \text { to } 120 \mathrm{~cm} \text {, depending on conditions ; } \\
\text { - Cycle at maturity: Early sowing; } \\
\text { - This variety is highly adapted in terms of productivity both in borage and irrigated zones, it } \\
\text { is recommended for sub-humid regions (Gharb, North-West). }\end{array}$ & INRA- Morocco (1988) \\
\hline KANZ & $\begin{array}{l}\text { - Height of the plant: } 85 \text { to } 115 \mathrm{~cm} \text {, depending on conditions; } \\
\text { - Cycle at maturity: Early sowing; } \\
\text { - The cultivation of this variety is recommended for borage and semi-arid. } \\
\text { - Height of the plant: } 70 \text { to } 105 \mathrm{~cm} \text { depending on conditions; }\end{array}$ & F. Desprez- France (1988) \\
\hline RAJAE & $\begin{array}{l}\text { - Cycle at maturity: Early sowing; } \\
\text { - Cultivation of this variety is recommended for sub-humid regions (Gharb, Northwest, and } \\
\text { Irrigated). }\end{array}$ & INRA - Morocco (1993) \\
\hline
\end{tabular}

\section{(Anonymous 1, Anonymous 2)}

\section{Experimental Protocol}

The seeds were washed for 5 min with distilled water solely $(0 \mathrm{~g} / \mathrm{L} \mathrm{NaCl})$ or with water containing salt at different levels $(3,6,9$, and $12 \mathrm{~g} / \mathrm{L} \mathrm{NaCl})$. Then, they were immersed for $1 \mathrm{~min}$ in ethanol $(70 \%)$ and were then disinfected for 15 minutes in a bath of $30 \%$ sodium hypochlorite (bleach) containing $0,3,6,9$, or $12 \mathrm{~g} / \mathrm{L}$ of $\mathrm{NaCl}$. The seeds were then, rinsed with distilled water solely for the controls or with distilled water, supplemented with $\mathrm{NaCl}$ at $(3,6,9$, and $12 \mathrm{~g} / \mathrm{l})$. Subsequently, the seeds were put to germinate in Petri dishes of $9 \mathrm{~cm}$ in diameter between two discs of filter paper. 10 seeds are placed per Petri dish, and then 10 $\mathrm{ml}$ of saline solution $(0,3,6,9$, and $12 \mathrm{~g} / \mathrm{L} \mathrm{NaCl})$ was added. The cultures were incubated for 7 days at $25^{\circ} \mathrm{C}$.

A total of 1250 seeds were used according to a factorial design combining two factors in a complete randomized block device. The two factors being the variety with five levels (Amal, Arrehane, Kanz, Radia, and Rajae) and salinity with also five levels $(0,3,6,9$, and $12 \mathrm{~g} / \mathrm{L} \mathrm{NaCl})$. For each of the 25 combinations of the two factors, 50 seeds were tested, 5 repetitions of 10 seeds per Petri dish.

The counting of germinated seeds was day-to-day; the radicle breakthrough and the emergence of coleoptile were noted every 24 hours, during 7 days of the germination test. Only seeds showing coleoptile and root growth length more than 2 millimeters were considered germinated. According to ISTA (the International Seed Testing Association), the germination of a seed is defined as " the emergence and development of the seedling to a stage where the aspect of its essential structures indicates whether or not it is able to develop further into satisfactory plant under favorable conditions in the field" (Anonymous 3)

\section{Measurements}

To compare the behavior of the five wheat varieties with respect to salinity, the following parameters were assessed:

\section{Germination rate $[\mathrm{G}(\%)=(\mathrm{NGi} / \mathrm{S}) .100]$}

The percentage of germination indicates the number of germinating seeds per lot. The germination rate thus indicates the number of seeds germinated for $\mathrm{i}$ days (NGi is the number of seeds counted from the beginning of the test up to the day i) expressed as a percentage of the number of tested seeds ( $\mathrm{S}$ being the number of seeds sown at the start of the test).

\section{Final germination rate $[\mathrm{GF}(\%)=(\mathrm{Nf} / \mathrm{S}) .100]$ :}

In our case, it is determined by the number of germinations obtained at the end of the experiment $(\mathrm{Nf})$, expressed as a percentage of the number of tested seeds ( $\mathrm{S}$ ). This capacity of germination, expressed as a percentage of sown seeds that germinated throughout the experimental period, was highlighted by the categories of Ruiz and Devesa (1998): none (0\%), low $(0<30 \leq \%<70)$, high $(70 \leq \%<100)$ and maximum $(100 \%)$.

\section{Reduction percentage of germination $(\mathrm{RPG}=100 .[1-(\mathrm{Nx} / \mathrm{N} 0)])$}

With $\mathrm{Nx}$ being the number of seeds germinated with salt treatment at $\mathrm{x} \mathrm{g} / \mathrm{l} \mathrm{NaCl}$ and $\mathrm{N} 0$ being the number of germinated seeds in the control $(0 \mathrm{~g} / \mathrm{l} \mathrm{NaCl})$.

For the RPG, we used the following categories: none $(0 \%)$, very low (inferior than $20 \%)$, low $(20<\%<40 \%)$, moderate $(40<\%<60 \%)$, high $(60<\%<80 \%)$, very high $(80<\%<100 \%)$ and total $(100 \%)$.

Corrected Germination $\left[\mathrm{CG}=100 .\left(\mathrm{Ni}\right.\right.$ - $\left.\left./ \mathrm{Ni} \_0\right)\right]$
According to Smith and Dobrenz (1987) with $\mathrm{Ni}_{-} \mathrm{x}$ being the number of germinated seeds from the beginning to the day $i$ at $x$ g/l NaCl and Ni_0 being the number of germinations from the beginning to the day at $0 \mathrm{~g} / \mathrm{l} \mathrm{NaCl}$.

Average time of germination $[\mathrm{ATG}=\Sigma \mathrm{Ni} \mathrm{Ti} / \Sigma \mathrm{Ni}]$ according to Czabator (1962):

with $\mathrm{Ni}$ being the number of seeds newly germinated at time $\mathrm{Ti}$; $\mathrm{Ni}+1$ being the number of seeds that have germinated between the time $\mathrm{Ti}$ and $\mathrm{Ti}+1$

Velocity coefficient $[\mathrm{CV}=100(\mathrm{~N} 1+\mathrm{N} 2+\ldots+\mathrm{Nx}) /(\mathrm{N} 1 \mathrm{~T} 1+\ldots+\mathrm{NxTx})$ according to Kotowski (1926):

With $\mathrm{N}$ : number of newly germinated seeds every day $\left(1^{\text {st }}, 2^{\text {nd }}, 3^{\text {rd }}\right.$ day, and so on until the last day ' $x$ ': otherwise it is the cumulative number of germination [Ni counted up to Ti day, minus the cumulative number of germinated seeds [Ni-1] counted up to Ti-1 day); $\mathrm{T}$ : duration in days corresponding to $\mathrm{N}$.

Germination index [GI= (Ni Ti) / S] according to Scott et al. (1984):

with Ti: number of days after seeding; Ni: number of germinations newly seen on the day $\mathrm{i}$ (otherwise it is the total number of germinations recorded up to $\mathrm{Ti}$ minus the cumulative number of germinated seeds up to Ti-1); S: number of seeds tested.

Germination rate index $[\mathrm{GRI}=\mathrm{G} 1 / 1+\mathrm{G} 2 / 2+\ldots+\mathrm{Gn} / \mathrm{n}]$ according to AlKaraki (1998):

With G1 being the germination percentage on day one; G2 on the 2nd day, etc ...; $\mathrm{n}$ being the number of days that the experiment lasts (7th in our case).

Germination vigour index $[\mathrm{GVI}=(\mathrm{a} / 1+\mathrm{b} / 2+\mathrm{c} / 3 \ldots+\mathrm{z} / \mathrm{n}) \times 100 / \mathrm{S}]$ according to Jain and Saha (1971)

with $\mathrm{a}, \mathrm{b}, \mathrm{c}, \ldots, \mathrm{z}$ being the number of seeds that germinate each day; $\mathrm{n}$ being the number of days that the experiment lasts $\left(7^{\text {th }}\right.$ in our case); S: number of seeds tested.

The rates were used to estimate the germination rate according to Cabello et al., (1998): Slow $(0 \leq \mathrm{VIG}<5)$, medium $(5 \leq \mathrm{VIG} \leq 11.11)$, fast $(11.11<\mathrm{VIG} \leq$ $33.33)$ and very fast $(33.33<\mathrm{VIG} \leq 100)$.

Mean daily germination $\left[\mathrm{MDG}=\% \mathrm{Gf} / \mathrm{x}^{\text {th }}\right.$ day of the test $]$ : According to Osborne et al (1993):

With the $\mathrm{x}^{\text {th }}$ day of the test: day when the number of germinations reaches its maximum for each repetition.

After 7 days of germination, the length of the coleoptiles (LC) and roots (LR) is also measured.

\section{Statistical Analysis of Data}

To highlight the effect of the different factors and their possible interactions, analysis of variance (ANOVA) with two (variety and salinity) and three (variety, salinity, and duration) classification criteria was performed. In the case of ANOVA2, the device is in a completely random block whereas for the ANOVA3 the device is a split-plot with the combination of both factors (variety and salinity) in large plots and the duration factor of the germination in small plots (Pendergast and Littell, 1988). Percentage data were subjected to an angular 
transformation (square root arc sinus) before being analyzed for variance (Zar, 1999). Significant effects were then subjected to multiple comparisons of means by the Tukey HSD (Honestly Significant Difference) test at the risk of error of 0.05 .

\section{RESULTS}

\section{Effects on daily germination rate (G \%)}

The kinetics of germination shows that the germination rate increases with time, but seems to stabilize from the $4^{\text {th }}-5^{\text {th }}$ day or beyond at higher saline levels (Figure 1). The graphs, show a plateau representing the final percentage of germination and reflecting the daily germination capacity of each variety and for each saline concentration. The germination capacity of the stressed seeds of the five wheat varieties is variable compared to the control. This variability is strongly marked by the salt concentration effect.

On the 7th day, at concentrations 3 and $6 \mathrm{~g} / \mathrm{l} \mathrm{NaCl}$, Amal, Arrehane, Radia and Rajae varieties did not produce very different results from the control $(0 \mathrm{~g} / \mathrm{l}$
$\mathrm{NaCl}$ ). However, the highest salt concentrations (9 and $12 \mathrm{~g} / \mathrm{l})$ lead to significant germination rate reductions and more particularly at $12 \mathrm{~g} / \mathrm{l} \mathrm{NaCl}$.

Kanz variety appears relatively more sensitive since; the reductions are noticeable from $3 \mathrm{~g} / \mathrm{l} \mathrm{NaCl}$, and are more marked at $6 \mathrm{~g} / 1 \mathrm{NaCl}$. However, the highest salt concentrations $(9$ and $12 \mathrm{~g} / \mathrm{l} \mathrm{NaCl}$ ) practically lead to the same drastic reductions in all varieties.

The statistical analysis for the variable $G(\%)$ reveals very highly significant differences for the effects of the variety, salinity, and duration as well as for the interactions of "duration* variety", "salinity*variety", and significant differences for the interaction of "duration* salinity*variety". However, this parameter is more controlled by the varietal factor (Tab 2). The ranking of averages for al concentrations combined (Tab 3), shows five different groups for the variety effect (Rajae $>$ Amal $>$ Arréhane $>$ Kanz $>$ Radia), five groups for the salinity effect $(\{0\}>\{3\}>\{6\}>\{9\}>\{12\} \mathrm{g} / \mathrm{L} \mathrm{NaCl})$, and six groups for the duration $\left(\left\{7^{\text {th }}\right.\right.$ and $\left.6^{\text {th }}\right\} \geq\left\{5^{\text {th }}\right\} \geq\left\{4^{\text {th }}\right\}>\left\{3^{\text {rd }}\right\}>\left\{2^{\text {nd }}\right\}>\{1\}$ days .

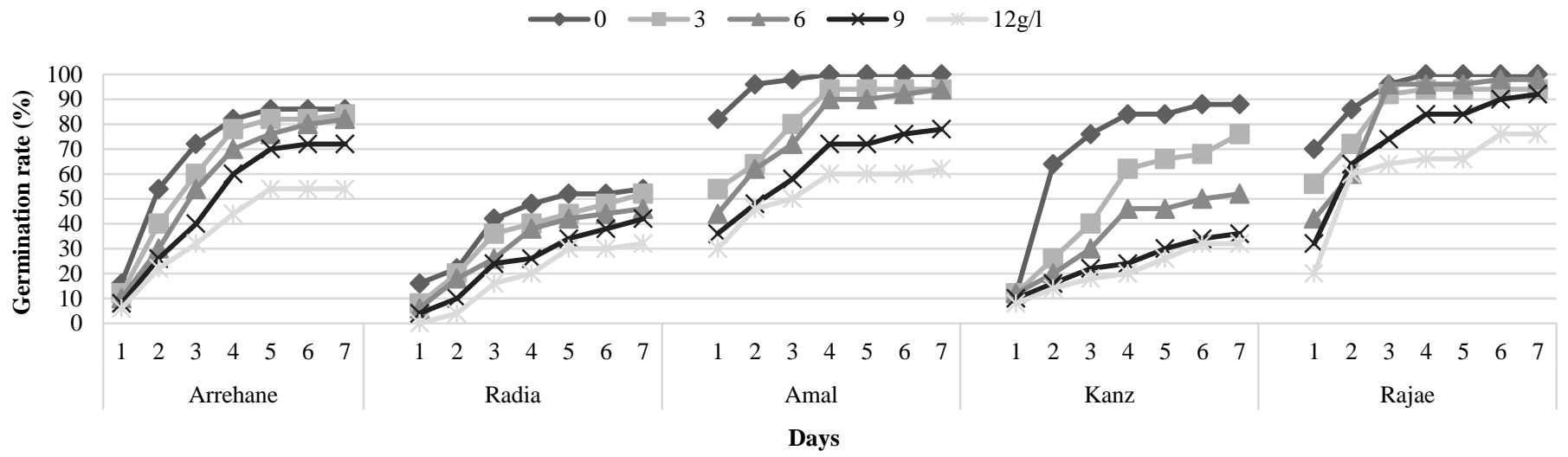

Figure 1 Evolution of the germination rate (\%) of wheat varieties (Amal, Arrehane, Kanz, Radia, and Rajae) in response to exposure duration and salt concentration

Reduction percentage in germination (RPG) compared to control

During the first three days, the reduction percentage in germination compared to the control (Tab. 2) is engendered by salinity in Amal, Arrehane, Radia, and Rajae at 3 and $6 \mathrm{~g} / \mathrm{L} \mathrm{NaCl}$ and during the whole test at 9 and $12 \mathrm{~g} / \mathrm{L} \mathrm{NaCl}$. However, for Kanz, the RPG remains favorable throughout the test
Moreover, on the $4^{\text {th }}$ day, the RPG at $6 \mathrm{~g} / \mathrm{L} \mathrm{NaCl}$ is very low (less than $20 \%$ ), except for Kanz which remains disadvantaged by showing moderate values (between 40 and 60\%). Furthermore, at $9 \mathrm{~g} / \mathrm{L} \mathrm{NaCl}$, the Arrehane and Rajae varieties retain very low RPGs. However, at the same concentration, the Amal and Radia varieties show low values (between 20 and 40\%) in contrast to Kanz, which is more disadvantaged and has high RPGs (between 60 and $80 \%$ ).

Table 2 The reduction Percentage of germination compared to control depending on salinity levels and duration for the five varieties (Amal, Arrehane, Kanz, Radia, and Rajae)

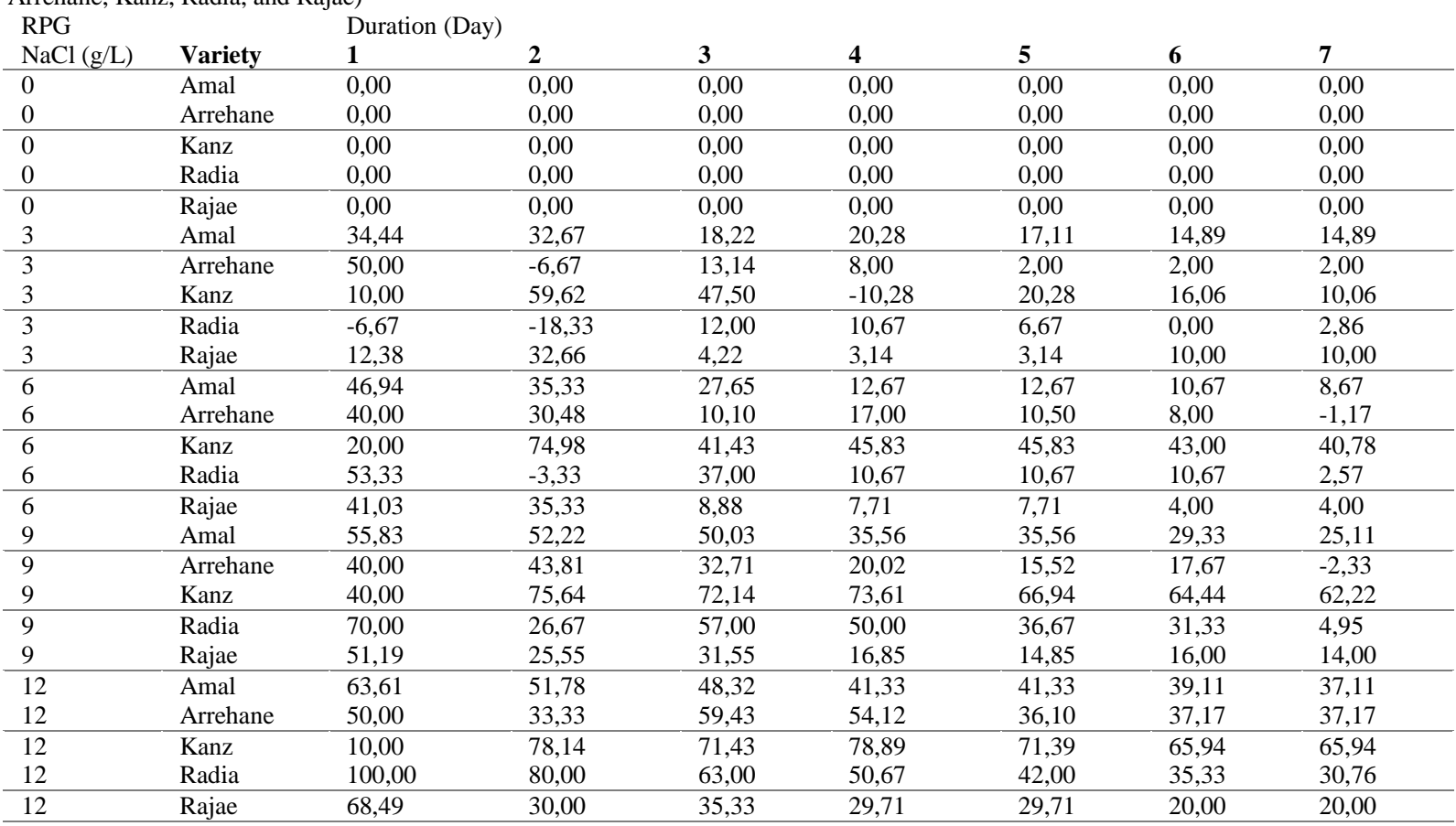

However, at $12 \mathrm{~g} / \mathrm{L} \mathrm{NaCl}$, Amal, Arrehane and Rajae varieties retain feeble RPGs and Radia shows moderate values while Kanz has the highest RPG.

The variance analysis for the RPG variable shows very highly significant differences for the variety and salinity and the germination duration duration, as well as, for the interactions of "duration * variety", "salinity * variety". Yet, this criterion is more marked by the salinity factor (Tab 2). The ranking of average (Tab 3) distinguishes four groups for the variety effect ( $\{$ Kanz $\}>\{$ Radia and Amal $\} \geq\{$ Arrehane $\} \geq\{$ Rajae $\}$, five groups for the salinity effect $(\{0\}<\{3\}<$ 
$\{6\}<\{9\}<\{12\} \mathrm{g} / \mathrm{L} \mathrm{NaCl})$ and four groups for the duration effect $\left(\left\{7^{\text {th }}\right\}<\left\{6^{\text {th }}\right\}\right.$ $\leq\left\{5^{\text {th }}\right.$ and $\left.4^{\text {th }}\right\} \leq\left\{3^{\text {rd }}\right\} \leq\left\{2^{\text {nd }}\right\} \leq\left\{1^{\text {st }}\right\}$ days $)$.

\section{Effects on corrected germination (CG)}

The corrected germination was calculated from the $1^{\text {st }}$ day of the test (Figure 3 ) and revealed a negative effect of salt on seeds' germination. On the $7^{\text {th }}$ day, the recorded values of reduction percentage for the corrected germination at $12 \mathrm{~g} / \mathrm{L}$ $\mathrm{NaCl}$ were $24 \%, 38 \%, 38 \%, 39 \%$ and $63 \%$ respectively for Rajae, Amal, Arrehane, Radia and Kanz, which our findings for on the germination rate for each variety.
Statistically, the analysis of the variable CG (\%) reveals very significant differences for the effects of variety, salinity and duration as well as for the "duration * variety" and "salinity * variety" interactions. Furthermore, the ANOVA shows that this variable is strongly influenced by the salinity factor (Tab 2). The ranking of the means (Tab 3 ) for all concentrations combined shows five groups for the salinity effect $(\{0\}>\{3\}>\{6\}>\{9\}>\{12\} \mathrm{g} / \mathrm{L} \mathrm{NaCl})$, five different groups for the effect variety ( $\{$ Rajae $\} \geq\{$ Arréhane $\} \geq\{$ Amal and Radia $\}>\{$ Kanz $\})$, and six groups for the duration $\left(\left\{7^{\text {th }}\right.\right.$ and $\left.6^{\text {th }}\right\} \geq\left\{5^{\text {th }}\right\} \geq\left\{4^{\text {th }}\right\} \geq$ $\left\{3^{\text {rd }}\right\} \geq\left\{2^{\text {nd }}\right\}>\left\{1^{\text {st }}\right\}$ days $)$.

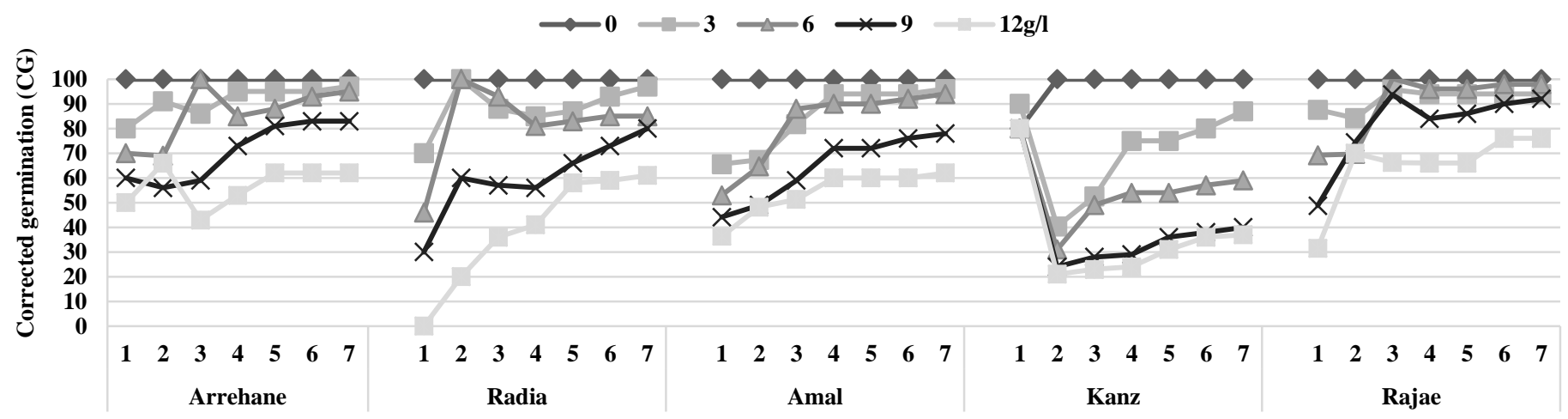

Days

Figure 2 Evolution of the corrected germination (\%) of wheat varieties (Amal, Arrehane, Kanz, Radia, and Rajae) in response to duration and salt concentration

Table 2 ANOVA results to test for differences in G (\%), RPG (\%) and CG (\%) across the five varieties, five salinity levels, and seven durations.

\begin{tabular}{|c|c|c|c|c|}
\hline & & & Sum of Squares & \\
\hline Source of variation & DF & CG $(\%)$ & RPG (\%) & G $(\%)$ \\
\hline Duration (Day) & 6 & $34543,74 * * *$ & $30932,64 * * *$ & $227756,57 * * *$ \\
\hline $\mathrm{NaCl}(\mathrm{g} / \mathrm{L})$ & 4 & $257722,31 * * *$ & $256527,08 * * *$ & 131485,26 *** \\
\hline Duration $($ Day $) * \mathrm{NaCl}(\mathrm{g} / \mathrm{L})$ & 24 & $8801,85^{\text {ns }}$ & $12018,86^{\mathrm{ns}}$ & $7097,14 * * *$ \\
\hline Variety & 4 & $65403,60 * * *$ & $69204,75 * * *$ & $312041,83^{* * *}$ \\
\hline Duration (Day)*Variety & 24 & 48000,90 **** & $57029,77 * * *$ & $15972,57 * * *$ \\
\hline $\mathrm{NaCl}(\mathrm{g} / \mathrm{L}) *$ Variety & 16 & $23868,57 * *$ & $36777,49 * * *$ & $17018,74 * * *$ \\
\hline $\begin{array}{l}\text { Duration (Day)* NaCl } \\
(\mathrm{g} / \mathrm{L})^{*} \text { Variety }\end{array}$ & 96 & $47618,50^{\mathrm{ns}}$ & $55355,14^{\mathrm{ns}}$ & $17190,86^{*}$ \\
\hline Model & 174 & $485959,45 * * *$ & $517845,73 * * *$ & $728562,97 * * *$ \\
\hline Error & 700 & 456023,34 & 456738,43 & 93040,00 \\
\hline C. Total & 874 & 941982,79 & 974584,16 & 821602,97 \\
\hline
\end{tabular}

$*, * *, * * *$ : significant at $5 \%, 1 \%$ and $0.1 \%$ level, respectively; and ns: not significant. DF: Degree of freedom.

Table 3 Effect comparison of $\mathrm{NaCl}$ concentration, variety, Duration, and their interaction on G, CG, and RPG in wheat. Data are presented by means $( \pm \mathrm{SE})$.

Parameter

\begin{tabular}{llll}
\hline & CG $(\%)$ & RPG $(\%)$ & G $(\%)$ \\
$\mathbf{N a C l}(\mathbf{g} / \mathbf{L})$ & & & \\
\hline $\mathbf{0}$ & $99,43 \pm 0,57^{\mathrm{a}}$ & $0,00 \pm 0,00^{\mathrm{e}}$ & $74,11 \pm 2,14^{\mathrm{a}}$ \\
$\mathbf{3}$ & $86,42 \pm 2,43^{\mathrm{b}}$ & $13,18 \pm 2,57^{\mathrm{d}}$ & $63,14 \pm 2,20^{\mathrm{b}}$ \\
\hline $\mathbf{6}$ & $76,72 \pm 2,27^{\mathrm{c}}$ & $23,55 \pm 2,42^{\mathrm{c}}$ & $57,37 \pm 2,29^{\mathrm{c}}$ \\
$\mathbf{9}$ & $63,25 \pm 2,22^{\mathrm{d}}$ & $35,73 \pm 2,21^{\mathrm{b}}$ & $47,83 \pm 2,16^{\mathrm{d}}$ \\
\hline $\mathbf{1 2}$ & $50,41 \pm 2,49^{\mathrm{e}}$ & $49,21 \pm 2,49^{\mathrm{a}}$ & $38,57 \pm 1,83^{\mathrm{e}}$ \\
Variety & & & \\
\hline Amal & $76,48 \pm 1,71^{\mathrm{b}}$ & $23,21 \pm 1,70^{\mathrm{b}}$ & $74,34 \pm 1,77^{\mathrm{b}}$ \\
Arrehane & $81,34 \pm 2,15^{\mathrm{ab}}$ & $17,91 \pm 2,36^{\mathrm{bc}}$ & $56,00 \pm 2,16^{\mathrm{c}}$ \\
\hline Kanz & $59,68 \pm 3,36^{\mathrm{c}}$ & $40,50 \pm 3,26^{\mathrm{a}}$ & $40,69 \pm 2,06^{\mathrm{d}}$ \\
Radia & $73,94 \pm 2,78^{\mathrm{b}}$ & $25,25 \pm 2,90^{\mathrm{b}}$ & $30,40 \pm 1,40^{\mathrm{e}}$ \\
\hline Rajae & $84,78 \pm 1,48^{\mathrm{a}}$ & $14,80 \pm 1,50^{\mathrm{c}}$ & $79,60 \pm 1,66^{\mathrm{a}}$ \\
$\mathbf{D u r a t i o n} \mathbf{( d a y )}$ & & & \\
\hline $\mathbf{1}$ & $65,71 \pm 4,63^{\mathrm{d}}$ & $34,02 \pm 4,64^{\mathrm{a}}$ & $24,24 \pm 2,11^{\mathrm{e}}$ \\
$\mathbf{2}$ & $69,28 \pm 3,54^{\mathrm{c}}$ & $29,92 \pm 3,57^{\mathrm{ab}}$ & $42,00 \pm 2,39^{\mathrm{d}}$ \\
\hline $\mathbf{3}$ & $70,33 \pm 2,55 \mathrm{~b}^{\mathrm{cd}}$ & $27,58 \pm 2,84^{\mathrm{abc}}$ & $54,72 \pm 2,51^{\mathrm{c}}$ \\
$\mathbf{4}$ & $77,01 \pm 2,36 \mathrm{a}^{\mathrm{bc}}$ & $22,98 \pm 2,36^{\mathrm{bcd}}$ & $64,16 \pm 2,50^{\mathrm{b}}$ \\
\hline $\mathbf{5}$ & $79,45 \pm 2,07^{\mathrm{ab}}$ & $21,02 \pm 2,09^{\mathrm{bcd}}$ & $67,36 \pm 2,33^{\mathrm{ab}}$ \\
$\mathbf{6}$ & $81,90 \pm 2,01^{\mathrm{a}}$ & $18,64 \pm 1,99^{9^{\mathrm{dd}}}$ & $69,76 \pm 2,26^{\mathrm{a}}$ \\
\hline $\mathbf{7}$ & $83,03 \pm 2,05^{\mathrm{a}}$ & $16,17 \pm 2,16^{\mathrm{d}}$ & $71,20 \pm 2,24^{\mathrm{a}}$
\end{tabular}


similar result compared to the final germination rate at $(0 \mathrm{~g} / \mathrm{L} \mathrm{NaCl})$. This result, suggests that this salt concentration does not have a negative influence on the final germination rate of the five varieties. Moreover, in Radia variety, the final germination rate is paradoxically favored by salinity particularly, at 6 and $9 \mathrm{~g} / \mathrm{L}$ $\mathrm{NaCl}$. The varieties "Amal, Arrehane and Rajae" are not affected at $6 \mathrm{~g} / \mathrm{L} \mathrm{NaCl}$ compared to Kanz variety that shows a moderate FG $(30<\%<70)$ at 6 and $9 \mathrm{~g} / 1$ $\mathrm{NaCl}$. At these two concentrations, the four other varieties have high FG $(70<\%$ $<100)$. However, at $12 \mathrm{~g} / \mathrm{l} \mathrm{NaCl}$, only Rajae variety maintains a high FG.
The statistical analysis for the FG variable shows very highly significant effects for both factors' variety and salinity and their interaction. However, this criterion is more influenced by the variety factor (Tab 4). The ranking of means (Tab 5) shows five different groups ( $\{$ Rajae $\} \geq\{$ Amal $\} \geq\{$ Arrehane $\}>\{$ Kanz $\}>$ $\{$ Radia $\}$ ) for the variety effect, and three groups for salinity ( $\{0$ and 3$\}>\{6$ and $9\}>\{12\} \mathrm{g} / \mathrm{L} \mathrm{NaCl})$.

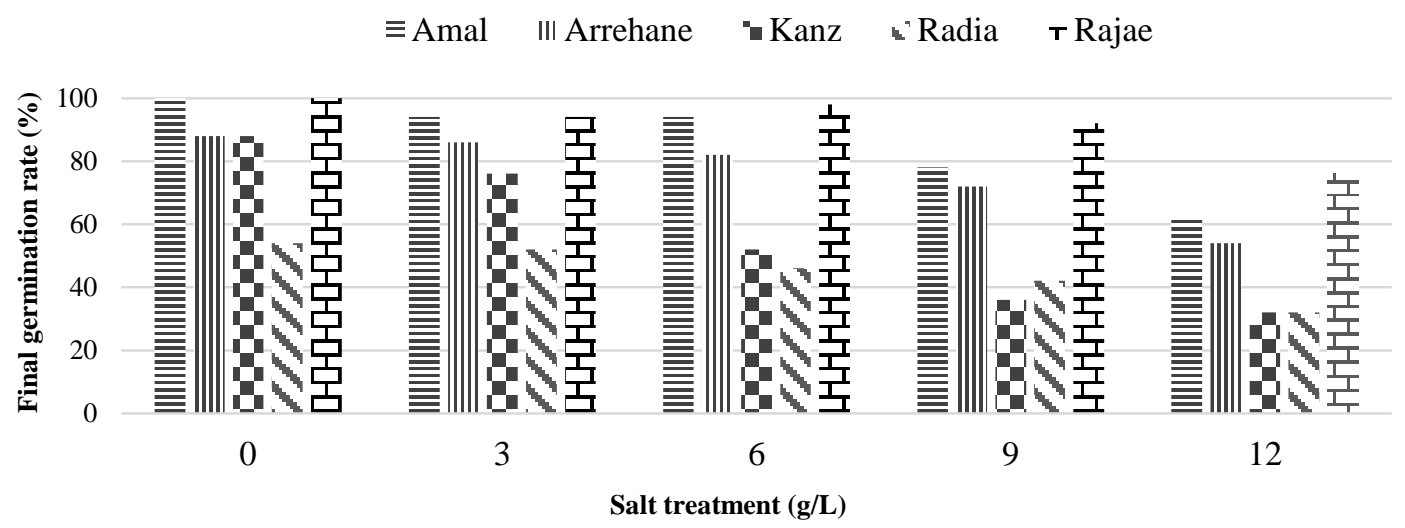

Figure 3 Evolution of the final germination rate (at the $7^{\text {th }}$ day) of wheat varieties (Amal, Arrehane, Kanz, Radia, and Rajae) in response to salt concentration.

\section{Effects on Average time of germination (ATG)}

ATG parameter varies according to the level of salinity and the variety (Figure 4). Indeed, increasing salinity to $9 \mathrm{~g} / \mathrm{L} \mathrm{NaCl}$ delays the germination, which causes an increase in the average time of germination. Also, the concentration of $12 \mathrm{~g} / \mathrm{L} \mathrm{NaCl}$ allows relatively, lower ATG compared with $9 \mathrm{~g} / \mathrm{L} \mathrm{NaCl}$.

Rajae variety always shows the lowest ATG (corresponding to a more rapid germination rate). Moreover, for the Arrehane variety, this parameter seems to be slightly affected by salinity, except at $9 \mathrm{~g} / 1 \mathrm{NaCl}$. At $12 \mathrm{~g} / \mathrm{L} \mathrm{NaCl}$ concentration, the highest average time of germination was recorded by Radia variety, followed by Kanz variety. However, at $3 \mathrm{~g} / \mathrm{L} \mathrm{NaCl}$, Kanz shows the highest ATG compared with the other varieties.

The analysis of variance for the ATG variable shows a very highly significant effect for both factors the variety and the salinity, and their interaction. However, this parameter is more controlled by the salinity factor (Tab 4). The ranking of the means (Tab 5) shows three groups for the variety effect (Rajae <Amal $<$ Arrehane and Kanz and Radia), and three groups for the effect of salinity $(\{0\}<$ $\{3$ and 6 and 12$\}<\{9\} \mathrm{g} / \mathrm{L} \mathrm{NaCl}$ ).

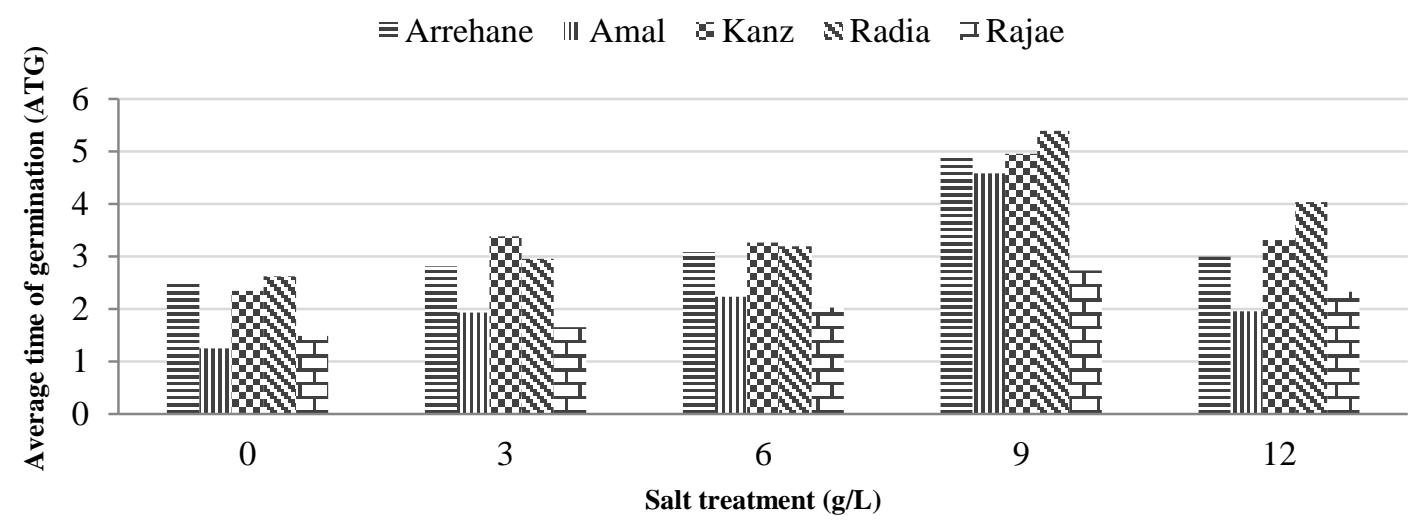

Figure 4 Average time of germination (days) of wheat varieties (Amal, Areehane, Kanz, Radia, and Rajae) in response to salt concentration.

\section{Effects on the velocity coefficient (VC)}

The velocity coefficient of germination is affected negatively by salinity (Figure 5). But, this criterion varies also depending on the variety. The varieties Rajae and Amal show the highest velocity coefficients of germination.
The analysis of variance for this variable shows a very highly significant effect, for variety and salinity and their interaction. The ranking of averages shows two groups for the variety effect (\{Radia, Kanz and Arrehane $\}<\{$ Amal and Rajae $\}$ ) and three groups for the salinity effect $(\{0\}>\{3,6$ and 12$\}>\{9\} \mathrm{g} / \mathrm{L} \mathrm{NaCl})$. 


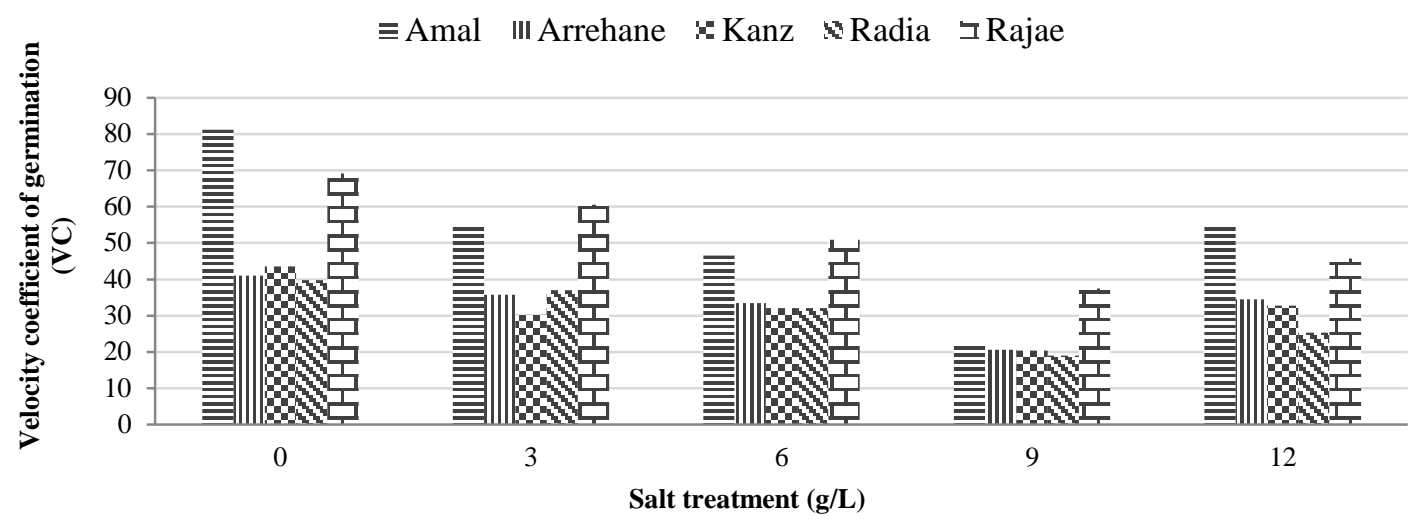

Figure 5 velocity coefficient of germination of wheat varieties (Amal, Areehane, Kanz, Radia, and Rajae) in response to salt concentration

\section{Effects on the germination index (GI)}

The germination index seems to be slightly or not affected at 3, and $6 \mathrm{~g} / \mathrm{L} \mathrm{NaCl}$ This criterion increased at 9 and $12 \mathrm{~g} / \mathrm{L} \mathrm{NaCl}$ respectively for Arrehane, Amal, Radia, and Kanz (Figure 6). Although in Rajae the GI remained feeble, this parameter did not vary with salinity.

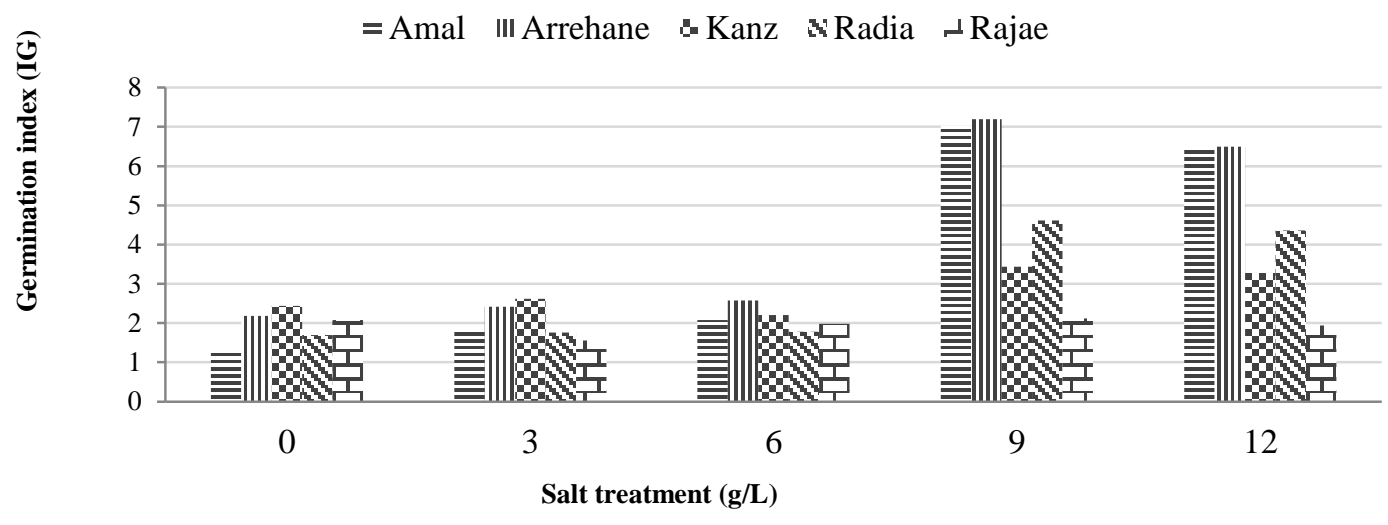

Figure 6 Germination index of wheat varieties (Amal, Areehane, Kanz, Radia, and Rajae) in response to salt concentration

\section{Effects on the germination rate index (GRI)}

The germination rate index decreases with salinity (Figure 7). In addition, Amal variety always shows the highest values followed by Rajae. On the other hand,

Radia variety records the lowest values.
The statistical analysis for the GI variable shows very highly significant differences, for variety and salinity, and their interaction. Moreover, this criterion is more marked by the variety factor (Tab 4). The ranking of means (Tab 5) exhibits, three groups for the variety effect $(\{$ Rajae $\}<\{$ Kanz and Radia $\}<$ $\{$ Arreehane and Amal $\})$ and two groups for the salinity effect $(\{0,3,6\}<\{9$ and $12\} \mathrm{g} / \mathrm{L} \mathrm{NaCl}$ ).

The results of the variance analysis for the GRI variable show very highly significant effects for variety and salinity as well as for the variety * salinity interaction (Tab 4). The ranking of means for the GRI variable (Ta 5) shows five groups for the variety effect (Amal $>$ Rajae $>$ Arréhane $>$ Kanz $>$ Radia) and five groups on the salinity effect $(\{0\}>\{3\}>\{6\}>\{9\}>\{12\} \mathrm{g} / \mathrm{L} \mathrm{NaCl})$.
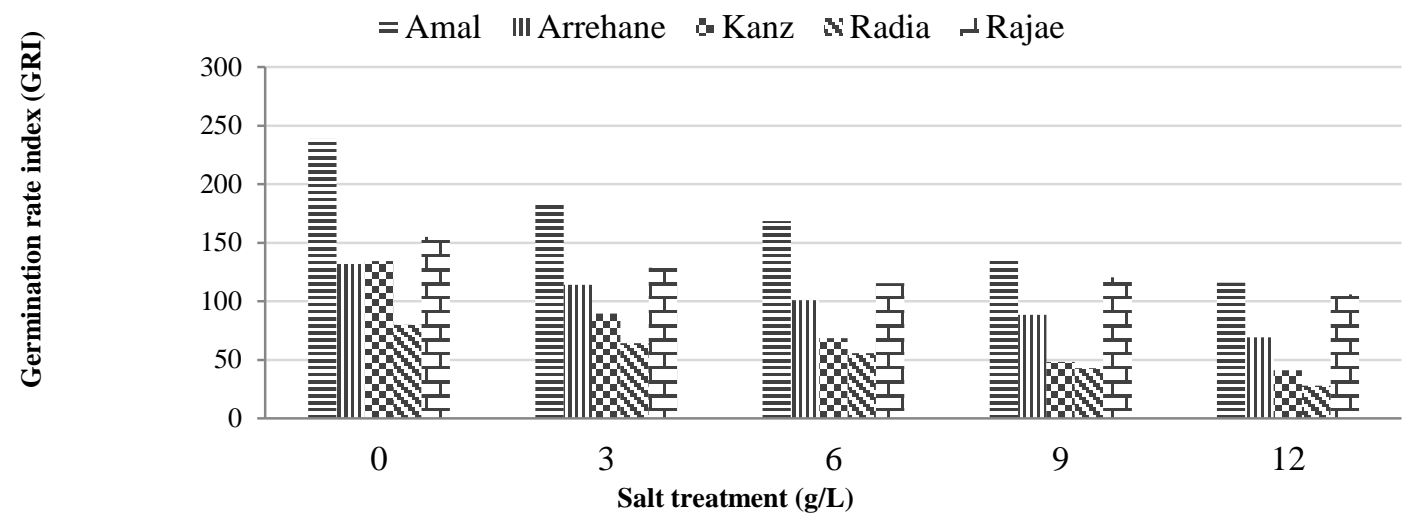

Figure 7 Germination rate index of wheat varieties (Amal, Areehane, Kanz, Radia, and Rajae) depending on salt concentration

\section{Effects on the germination vigor index of (GVI):}

The germination vigor index (Figure 8) varies depending on the salinity level, and wheat's variety tested. Consequently, this parameter decreased for the five varieties, particularly for Kanz and Radia. In contrast, Rajae and Amal varieties have the highest GVI values. For example, the percentage of variation for GVI was $47 \%, 48 \%, 53 \%, 64 \%$, and $68 \%$ respectively for Rajae, Arrehane, Amal, Kanz, and Radia varieties.

The analysis of variance for the variable GVI reveals a very highly significant effect for the variety and the salinity as well as a highly significant effect for their interaction (Tab 4). As for the effect of the variety there are four groups (\{Amal and Rajae $\}>\{$ Arréhane $\}>\{\operatorname{Kanz}\}>\{$ Radia $\})$ for the effect of salinity and four groups $(\{0\}>\{3\}>\{6$ and 9$\}>\{12\} \mathrm{g} / \mathrm{L} \mathrm{NaCl})($ Tab5). 


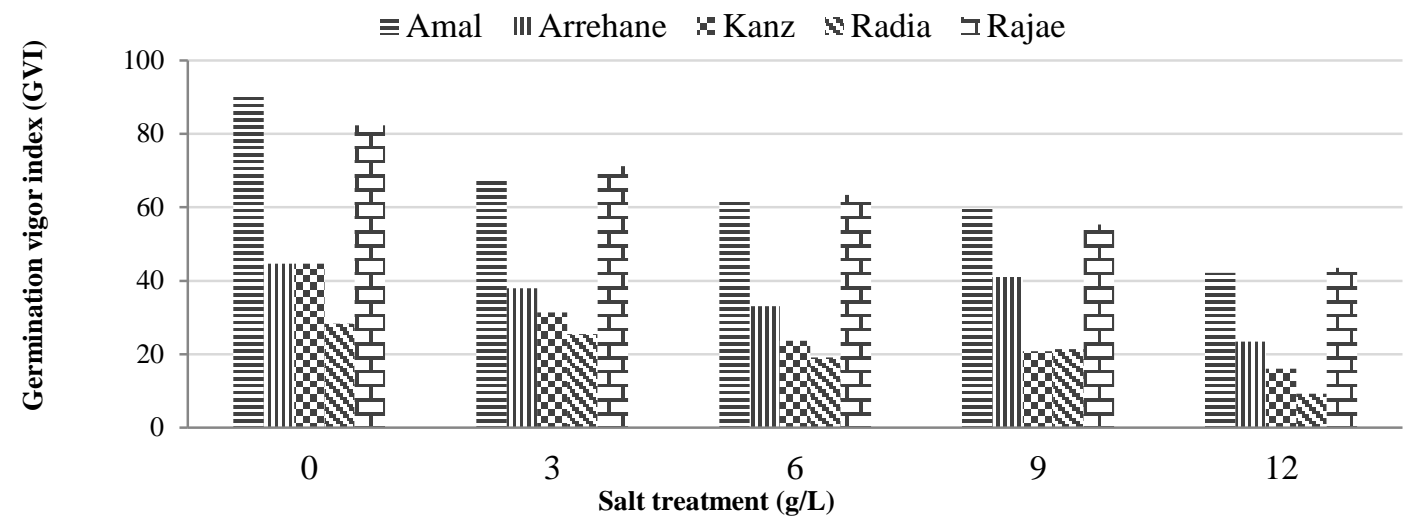

Figure 8 Germination vigor index of wheat varieties (Amal, Areehane, Kanz, Radia, and Rajae) in response to salt concentration

\section{Effects on the mean daily germination (MDG):}

The increase of $\mathrm{NaCl}$ concentration decreases the daily average germination of the five varieties of wheat (Figure 9). Statistically, the results show that $3 \mathrm{~g} / \mathrm{L}$ $\mathrm{NaCl}$ concentration does not have a negative influence on the MDG of all varieties. The values registered for this criterion (at all salt concentrations combined) remain more important for the variety Rajae followed by Amal in contrast with three other varieties.
The analysis of the variance for the variable MDG shows very highly significant differences, for the factors of variety and salinity and their interaction. Yet, this parameter is more controlled by the variety effect (Tab 4). The ranking of means (Tab 5) shows four groups (Rajae $>$ Amal $>\{$ Arréhane $\}>\{$ Kanz and Radia $\}$ ) for the variety effect and five groups for salinity factor $(\{0\}>\{3\} \geq\{6\} \geq\{9\} \geq\{12\}$ $\mathrm{g} / \mathrm{L} \mathrm{NaCl})$.

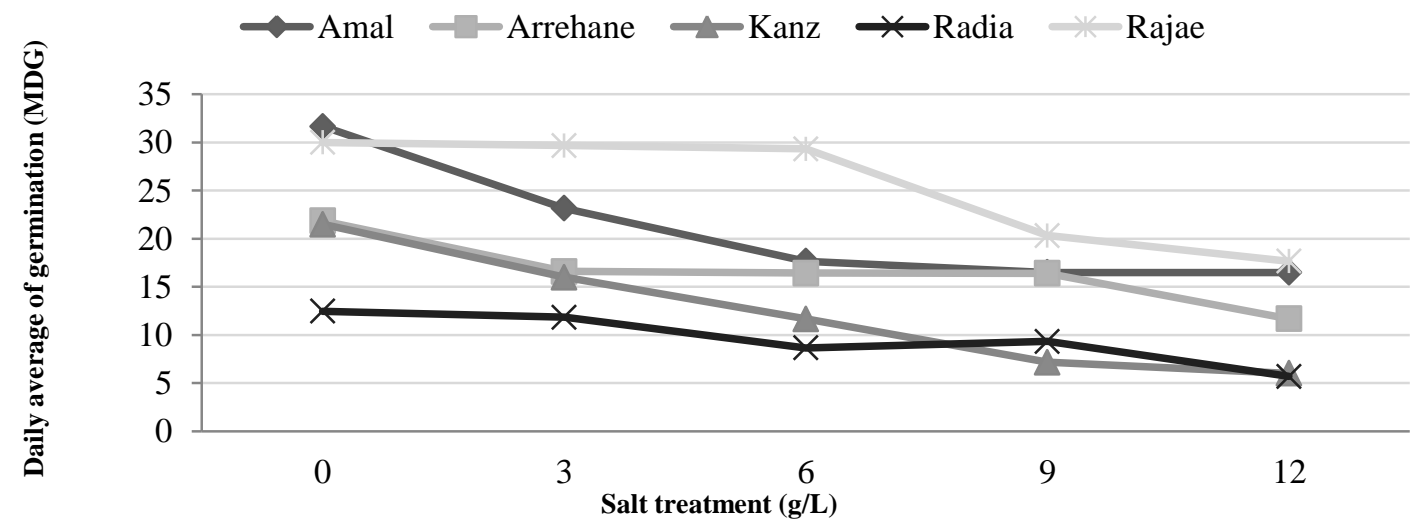

Figure 9 Daily average of germination of wheat varieties (Amal, Areehane, Kanz, Radia, and Rajae) in response to salt concentration shows three different groups for the variety effect (Rajae> AAmal and Arréhane $\}>\{$ Kanz and Radia $\})$ and five different groups for the effect of salinity $(\{0\}>\{3\}>\{6\}>\{9\}>\{12\} \mathrm{g} / \mathrm{L} \mathrm{NaCl})$. For the root length (LR) variable, the analysis of variance shows highly significant effects for both the variety and salinity factors. However, the effect of salinity is more pronounced than that of variety. On the other hand, the interaction between the two factors was found to be non-significant (Tab 4). The ranking of means for this parameter (Tab 5) shows four different groups for the effect of the variety ( $\{$ Rajae $\}>\{$ Arréhane $\} \geq$ $\{$ Amal $\}>\{$ Kanz and Radia $\})$ and five different groups for the effect of salinity $(\{0\}>\{3\}>\{6\}>\{9\}>\{12\} \mathrm{g} / \mathrm{L} \mathrm{NaCl})$. The variance analysis, for the variable length of the coleoptiles (LC), shor a very highly significant difference for the two factors variety and salinity as well as for their interaction (Tab 4). The ranking of means for this parameter (Tab 5)

The length of the coleoptiles (Figure 10) and the roots (Figure 11) are affected by salinity for all the five varieties. As the concentration of salt increases the decrease in length (LC and LR) is gradually registered. But, the reduction in length is more remarkable at $6 \mathrm{~g} / \mathrm{L} \mathrm{NaCl}$ and more at $12 \mathrm{~g} / \mathrm{L} \mathrm{NaCl}$. However, Rajae variety always exposes the highest values of length for both coleoptile and

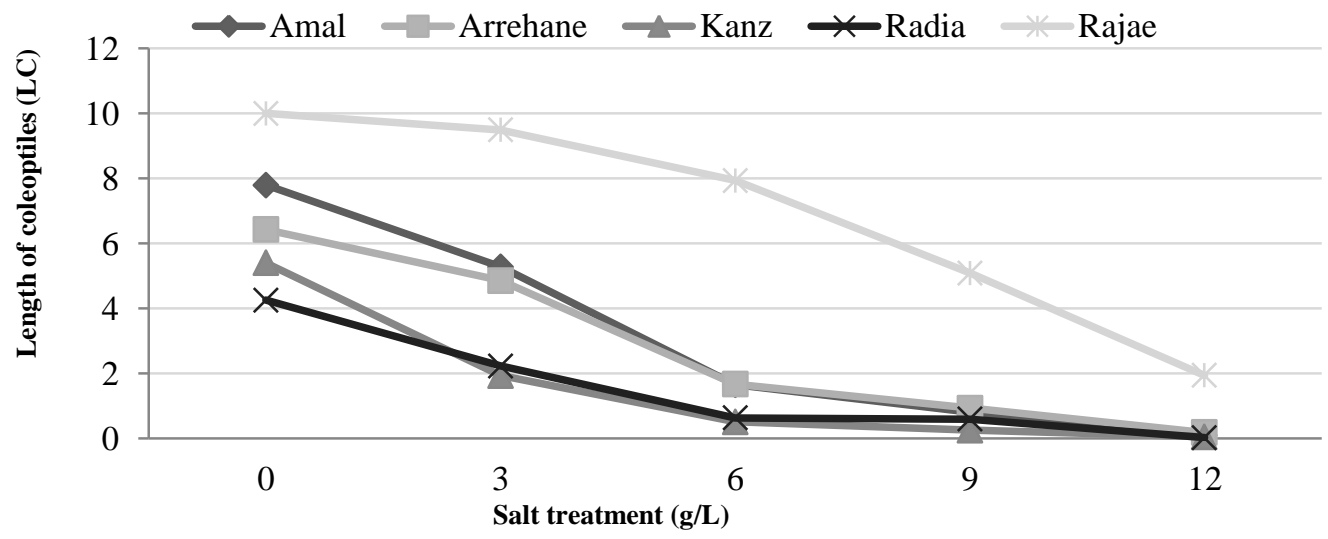

Figure 10 Length of coleoptiles of wheat varieties (Amal, Areehane, Kanz, Radia, and Rajae) in response to salt concentration 


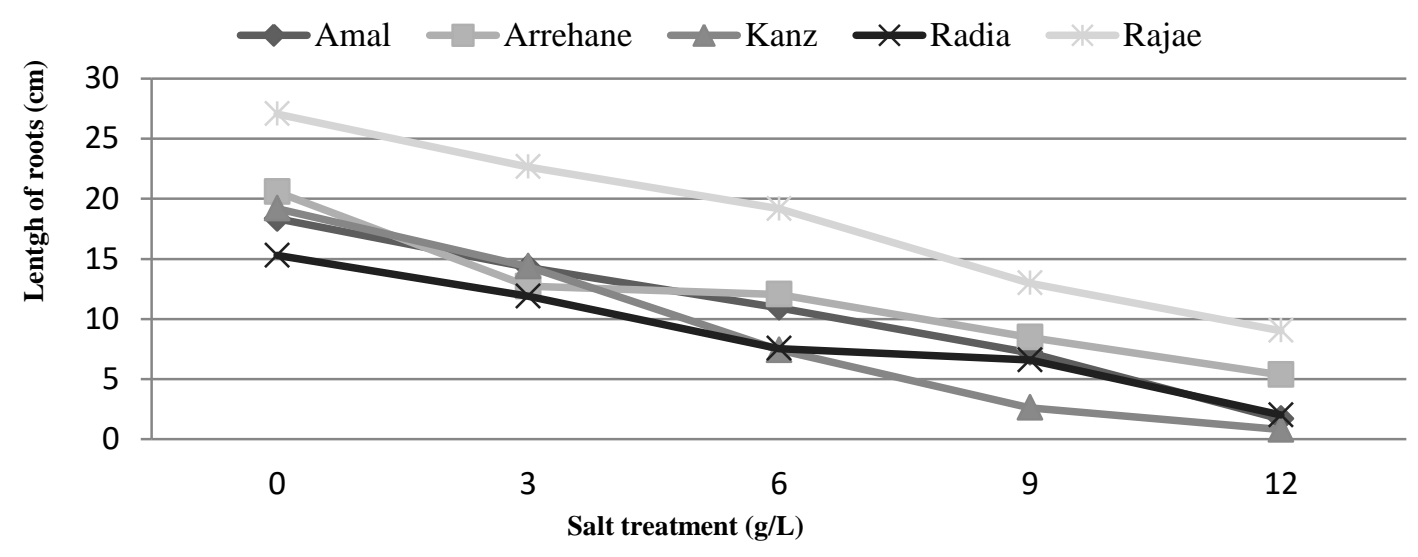

Figure 11 Length of the roots of wheat varieties (Amal, Areehane, Kanz, Radia, and Rajae) in response to salt concentration
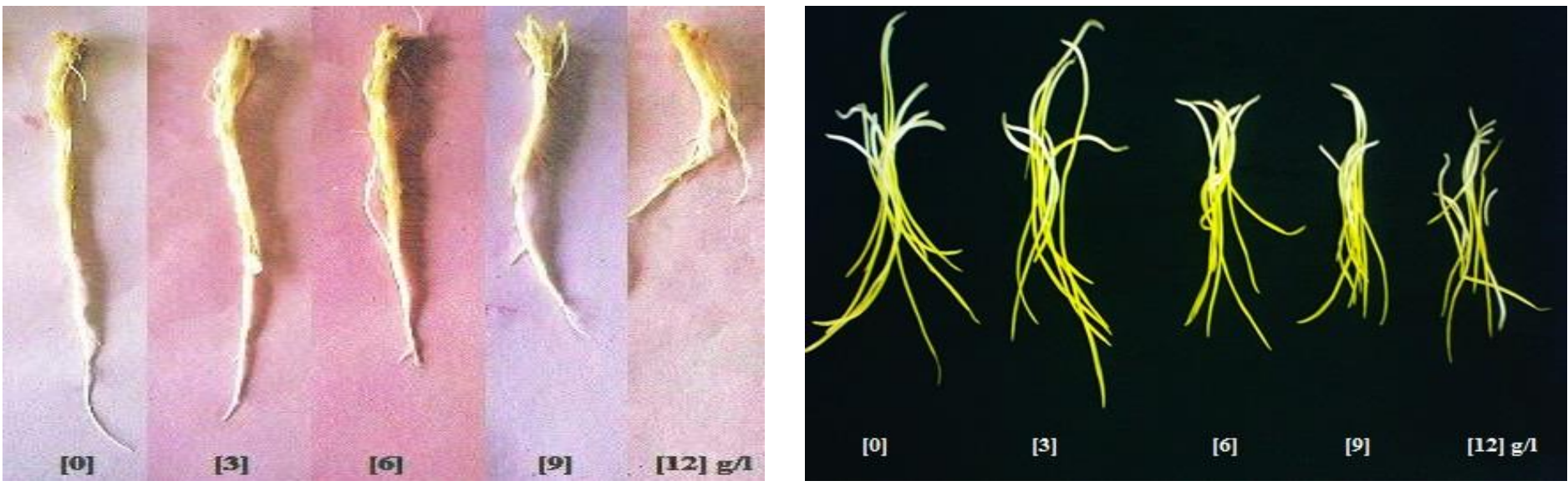

Figure 12 Effect of salt treatment on the length of roots and coleoptiles of wheat seeds after 7 days of salt treatment.

Table 4 ANOVA results to test for differences in parameters across five varieties and five salinity levels. Sum of Squares

\begin{tabular}{|c|c|c|c|c|c|c|c|c|c|c|}
\hline $\begin{array}{l}\text { Source of } \\
\text { variation }\end{array}$ & DF & $\mathrm{LC}(\mathrm{cm})$ & $\mathrm{LR}(\mathbf{c m})$ & GVI (\%) & $\begin{array}{l}\text { ATG } \\
\text { (Day) }\end{array}$ & $\mathrm{VC}(\%)$ & $\begin{array}{l}\text { GRI } \\
\text { (\% /day) }\end{array}$ & GI (Day) & FG (\%) & MDG (\%) \\
\hline $\mathrm{NaCl}(\mathrm{g} / \mathrm{L})$ & 4 & $650,66^{* * * *}$ & $4060,73 * * *$ & $12942,90 * * *$ & $79,78 * * *$ & $11302,00 * * *$ & $84790,75^{* * * *}$ & $216,01 * * *$ & $21820,80^{* * * *}$ & $2191,92 * * *$ \\
\hline Variety & 4 & $474,70 * * *$ & $1514,80 * * *$ & $41266,37 * * *$ & $53,13 * * *$ & $13714,69 * * *$ & $196635,13 * * *$ & $76,37 * * *$ & $31348,80^{* * * *}$ & 4069,37 *** \\
\hline $\begin{array}{l}\mathrm{NaCl}(\mathrm{g} / \mathrm{L}) \mathrm{x} \\
\text { Variety }\end{array}$ & 16 & $95,86 * * *$ & $05^{\mathrm{ns}}$ & $2415,51 * *$ & $15,78^{* * * *}$ & $3835,68 * * *$ & $14922,57 * *$ & $112,60 * * *$ & 20 **** & $586,68^{*}$ \\
\hline Model & 24 & $1221,22 * * *$ & $5780,58 * * *$ & $56624,77 * * *$ & $148,69 * * *$ & $28852,37 * * *$ & $296348,46^{* * *}$ & $404,98 * * *$ & $62804,80 * * *$ & $6847,97 * * *$ \\
\hline Error & 100 & 80,46 & 787,28 & 6771,33 & 29,84 & 7105,28 & 41481,83 & 91,78 & 16640,00 & 1685,77 \\
\hline C. Total & 124 & 1301,69 & 6567,87 & 63396,11 & 178,53 & 35957,65 & 337830,29 & 496,77 & 79444,80 & 8533,74 \\
\hline
\end{tabular}

$*, * *, * * *$ : significant at $5 \%, 1 \%$ and $0.1 \%$ level, respectively; and ns: not significant. DF: Degree of freedom.

Table 5 Effect comparison of $\mathrm{NaCl}$ concentration, variety, and their interaction on different parameters in wheat. Data are presented by means $( \pm \mathrm{SE})$.

\begin{tabular}{|c|c|c|c|c|c|c|c|c|c|}
\hline \multicolumn{10}{|l|}{ Parameters } \\
\hline & LC (cm) & LR (cm) & GVI (\%) & ATG (Day) & VC (\%) & GRI (\% /day) & GI (Day) & FG (\%) & MDG (\%) \\
\hline \multicolumn{10}{|l|}{$\mathrm{NaCl}(\mathrm{g} / \mathrm{L})$} \\
\hline $\mathbf{0}$ & $6,78 \pm 0,44^{\mathrm{a}}$ & $20,10 \pm 0,95^{\mathrm{a}}$ & $58,01 \pm 5,04^{\mathrm{a}}$ & $2,03 \pm 0,13^{\mathrm{c}}$ & $54,90 \pm 3,79^{\mathrm{a}}$ & $147,88 \pm 10,94^{\mathrm{a}}$ & $1,93 \pm 0,14^{\mathrm{b}}$ & $85,60 \pm 3,88^{\mathrm{a}}$ & $23,50 \pm 1,60^{\mathrm{a}}$ \\
\hline 3 & $4,76 \pm 0,62^{b}$ & $15,19 \pm 0,92^{\mathrm{b}}$ & $46,71 \pm 4,26^{\mathrm{b}}$ & $2,55 \pm 0,16^{\mathrm{b}}$ & $43,60 \pm 2,91^{\mathrm{b}}$ & $116,04 \pm 9,37^{b}$ & $2,03 \pm 0,14^{b}$ & $86,80 \pm 3,68^{\mathrm{a}}$ & $19,45 \pm 1,44^{\mathrm{b}}$ \\
\hline 6 & $2,48 \pm 0,58^{\mathrm{c}}$ & $11,43 \pm 1,04^{\mathrm{c}}$ & $40,09 \pm 4,19^{c}$ & $2,76 \pm 0,15^{\mathrm{b}}$ & $38,93 \pm 2,14^{b}$ & $101,67 \pm 8,97^{\mathrm{bc}}$ & $2,12 \pm 0,15^{b}$ & $75,20 \pm 4,73^{\mathrm{b}}$ & $16,75 \pm 1,65^{\mathrm{bc}}$ \\
\hline 9 & $1,54 \pm 0,38^{\mathrm{d}}$ & $7,58 \pm 0,91^{\mathrm{d}}$ & $39,62 \pm 3,53^{\mathrm{c}}$ & $4,42 \pm 0,24^{\mathrm{a}}$ & $25,35 \pm 2,19^{c}$ & $87,01 \pm 8,24^{\text {cd }}$ & $4,88 \pm 0,48^{\mathrm{a}}$ & $66,40 \pm 5,06^{\mathrm{b}}$ & $13,95 \pm 1,27^{\text {cd }}$ \\
\hline 12 & $0,46 \pm 0,16^{\mathrm{e}}$ & $3,78 \pm 0,73^{\mathrm{e}}$ & $26,83 \pm 3,23^{\mathrm{d}}$ & $2,93 \pm 0,20^{\mathrm{b}}$ & $38,66 \pm 2,98^{\mathrm{b}}$ & $71,88 \pm 8,12^{\mathrm{d}}$ & $4,51 \pm 0,42^{\mathrm{a}}$ & $51,20 \pm 4,41^{\mathrm{c}}$ & $11,52 \pm 1,26^{\mathrm{d}}$ \\
\hline \multicolumn{10}{|l|}{ Variety } \\
\hline Amal & $3,13 \pm 0,63^{\mathrm{b}}$ & $10,49 \pm 1,24^{\mathrm{bc}}$ & $64,26 \pm 3,81^{\mathrm{a}}$ & $2,39 \pm 0,25^{\mathrm{b}}$ & $51,86 \pm 4,41^{\mathrm{a}}$ & $168,40 \pm 10,21^{\mathrm{a}}$ & $3,72 \pm 0,53^{\mathrm{a}}$ & $86,00 \pm 3,51^{\mathrm{ab}}$ & $21,10 \pm 1,42^{\mathrm{b}}$ \\
\hline Arrehane & $2,81 \pm 0,53^{\mathrm{b}}$ & $11,84 \pm 1,18^{\mathrm{b}}$ & $35,96 \pm 1,90^{\mathrm{b}}$ & $3,25 \pm 0,19^{\mathrm{a}}$ & $33,03 \pm 1,65^{\mathrm{b}}$ & $100,78 \pm 5,39^{c}$ & $4,18 \pm 0,50^{\mathrm{a}}$ & $77,20 \pm 3,76^{\mathrm{b}}$ & $16,60 \pm 0,90^{\mathrm{c}}$ \\
\hline Kanz & $1,63 \pm 0,42^{\mathrm{c}}$ & $8,88 \pm 1,44^{\mathrm{c}}$ & $27,28 \pm 2,52^{\mathrm{c}}$ & $3,45 \pm 0,21^{\mathrm{a}}$ & $31,74 \pm 1,94^{\mathrm{b}}$ & $76,26 \pm 7,80^{\mathrm{d}}$ & $2,80 \pm 0,20^{\mathrm{b}}$ & $60,40 \pm 5,76^{\mathrm{c}}$ & $12,47 \pm 1,34^{\mathrm{d}}$ \\
\hline Radia & $1,55 \pm 0,36^{\mathrm{c}}$ & $8,67 \pm 1,26^{\mathrm{c}}$ & $20,64 \pm 1,68^{\mathrm{d}}$ & $3,64 \pm 0,24^{\mathrm{a}}$ & $30,58 \pm 2,16^{\mathrm{b}}$ & $54,00 \pm 4,52^{\mathrm{e}}$ & $2,84 \pm 0,34^{\mathrm{b}}$ & $49,60 \pm 3,94^{\mathrm{d}}$ & $9,60 \pm 0,74^{\mathrm{d}}$ \\
\hline Rajae & $6,89 \pm 0,63^{\mathrm{a}}$ & $18,18 \pm 1,35^{\mathrm{a}}$ & $63,12 \pm 3,10^{\mathrm{a}}$ & $1,95 \pm 0,10^{\mathrm{c}}$ & $54,24 \pm 2,55^{\mathrm{a}}$ & $125,03 \pm 4,56^{\mathrm{b}}$ & $1,94 \pm 0,11^{\mathrm{c}}$ & $92,00 \pm 2,24^{\mathrm{a}}$ & $25,40 \pm 1,51^{\mathrm{a}}$ \\
\hline
\end{tabular}




\section{DISCUSSION}

Germination is a key step in the development cycle of the plant. During this stage, the development of the radicle would be controlled by the osmolarity of the medium, whereas the subsequent growth of the seedling would be limited by the mobilization and transport of the reserves towards the embryonic axis (Gomes et al., 1983).

In this study, several morphological criteria namely, the germination rate, the corrected germination, the reduction percentage in germination, the fina percentage of germination, the mean daily germination, the germination index, the vigor index of germination, the germination rate index, the velocity coefficient, the average time of germination and the length of coleoptiles and roots, were used to study the impact of salt stress on seeds' germination of five wheat varieties grown in Morocco.

The obtained results showed that the seeds' germination of the five wheat varieties is affected negatively by the salt stress. The assessment of the studied parameters showed a reduction in the germination rate $\mathrm{G} \%$ and the final germination rate $\mathrm{FG} \%$ in response to the increase of salt concentration. Concerning the final germination rate, we found that the concentration of $3 \mathrm{~g} / \mathrm{l}$ $\mathrm{NaCl}$ shows approximately identical results to the control, thus it is moderately tolerated by all the five varieties studied. Related results have been reported in wheat, indicating that salinity affects the germination, not only by decreasing its rate but also, by delaying the beginning of germination (Hussain et al., 2013; Öner et al., 2018; Bhutto et al. (2018). Indeed, a direct and negative relationship was found by Eskandari and Kazemi (2011) between the germination rate and the increase of the salt concentration. The salt inhibitory effect on germination has also been reported in tomato by Mohamdi et al. (2011), in Safflower by Elouaer and Hannachi (2012), and in aromatic rice by Afzal et al. (2012).

According to Prado et $\boldsymbol{a l}$. (2000), the reduction of the seeds' germination rate under salt stress, is due to an osmotic dormancy process developed under these stress conditions, thus representing an adaptation strategy. Ben Naceur et al., (2001) have also, stated that the germination rate under salt stress always gives a more or less precise idea on the behavior of the varieties studied. In other glycophytes such as Jojoba (Simmondsia Chinensis), Berrichi et al., (2010) noted that from $3 \mathrm{~g} / \mathrm{L} \mathrm{NaCl}$, the germination is negatively affected.

Other researchers like Mrani Alaoui et al. (2013), have tested the response of six wheat varieties under salt stress effect, and have similarly noted that wheat is a sensitive plant towards $\mathrm{NaCl}$ action at germination stage. In various plant types, the germination and the growth phase are very sensitive to salinity. According to Almodares et al. (2007) and Maghsoudi Moud and Maghsoudi (2008), the reduction of germination under salt stress is related to the combined effect of osmotic stress, and the toxicity of accumulated ions. Moreover, the inability of seeds to germinate under saline conditions is due to inhibition of seed water absorption or embryo damage by $\mathrm{Na}^{+} / \mathrm{Cl}^{-}$(Mehmat et al., 2006, Saboota and Kiarostami, 2006).

The toxic effect due to the accumulation of $\mathrm{Na}^{+}$and $\mathrm{Cl}^{-}$ions in the embryo, may lead to the alteration of metabolic processes at the germination stage yet, at a most extreme case, to the death of the embryo over the excess of saline ions (Groome et al., 1991). During seed germination, additionally to enhancing osmotic potential, salinity leads to higher absorption of $\mathrm{Na}^{+}$and $\mathrm{Cl}^{-}$ions. Hence, provokes cellular toxicity and inhibits or delays the germination (Mehmet et al., 2013). In contrast at the growth stage, xerophytic plants, such as $P$. Cornutum, can accumulate a large amount of $\mathrm{Cl}^{-}$in its shoots, facilitating osmotic adjustment and turgor generation under saline conditions (Cui et al., 2020).

Relatively to the reduction percentage of germination, the recorded values were variable along with the increase in salt stress level. Rajae, Amal and Arrehane varieties retained very low (less than 20\%) and low (20-40\%) RPG values at high salinity. However, Radia showed an inferior RPGs (between 20 and 40\%) for 9 $\mathrm{g} / \mathrm{L} \mathrm{NaCl}$ to moderate (between 40 and $60 \%$ ) for $12 \mathrm{~g} / \mathrm{L} \mathrm{NaCl}$, whereas $\mathrm{Kanz}$ had a moderate RPG $(60 \%)$ at $6 \mathrm{~g} / 1 \mathrm{NaCl}$, and high (between 60 and $80 \%$ ) at 9 and $12 \mathrm{~g} / \mathrm{LNaCl}$. Furthermore, an increase in the average time of germination was jointly recorded. However, this extension of the ATG is low for Rajae and Amal (which explains that their germination is faster and their daily averages of germination are higher compared to the other varieties). However, the ATG appears more important for the Radia and Kanz varieties, while Arrehane registered intermediate values.

Conferring to Akbarimoghaddami et al., (2011), by increasing $\mathrm{NaCl}$ concentrations, the germination in the cultivars delayed and decreased. It seems obvious that the increase in external osmotic pressure related to the increase of salt concentration affects the rate of water absorption by the seeds and therefore extends the required average time for the germination. Indeed, the delay in seed germination with the increase in salinity and the decrease in average germination per day is due to the time required for the seed to set up mechanisms to adjust its osmotic pressure (Ben Miled et al., 1986, Bliss et al., 1986). Conversely, Botia et al. (1998) reported that the slowing of the germination could also be due to the alteration of enzymes and hormones in the seed. According to some studies, salinity also disrupts the enzymatic systems involved in different physiological functions of the germinating seeds, such as decreased polyphenol oxidase and amylase activity (Khemiri et al., 2004, Slama et al., 1992) and peroxidases (Iraida et al., 1999). Lachhab et al. (2013) also, concluded that salinity causes inhibition of the activity and expression of proteases that appear to be necessary for germination.

Our results, as well indicated a decrease in the velocity coefficient, the germination rate index, the germination vigor index, and the mean daily germination. It has been revealed that in wheat the germination rate and the germination rate index are significantly low as the salt concentration increases (Begum et al., 2010, Mirzaei et al., 2012).

Variables of the length of coleoptiles (LC) and roots (LR) have also, decreased as a result of salinity effect. El Goumi et al. (2014), have studied the effect of salinity on seed germination of three Moroccan barley (Hordeum vulgare L.) cultivars. They indicated that the increase in salt concentration decreases remarkably the final germination percent, and roots and shoots length Maghsoudi Moud and Maghsoudi (2008), suggested that the elongation measurement of roots and coleoptiles could be used as a screening criterion for wheat cultivars for improved salt stress tolerance.

Moreover, analysis of the variance for the studied criteria namely the germination rate, the corrected germination, and the length of coleoptile and root, studied throughout the germination process of the five varieties of wheat, allowed the same classification $(\{0\}>\{3\}>\{6\}>\{9\}>\{12\} \mathrm{g} / \mathrm{L} \mathrm{NaCl})$ of salt levels. However, another criterion, the reduction percentage of germination, permitted the same distinction of the five saline levels with a reasonably inverse hierarchy. For all the morphological parameters used, the germination in Kanz and Radia varieties was significantly influenced by increasing salt concentration, particularly at high concentrations $(9$ and $12 \mathrm{~g} / \mathrm{L} \mathrm{NaCl})$ compared to the control $(0 \mathrm{~g} / \mathrm{L} \mathrm{NaCl})$. While the recorded values for Rajae were always the highest. The adaptation behavior of this variety has been maintained from low salinity levels ( 3 and $6 \mathrm{~g} / \mathrm{L} \mathrm{NaCl}$ ) to the highest ( 9 and $12 \mathrm{~g} / \mathrm{NaCl}$ ). Amal and Arrehane varieties oscillated between intermediate positions.

In the light of the obtained results, the variety Rajae has shown to be tolerant to salinity, while the two varieties Kanz and Radia are the most sensitive. As a result, this preliminary varietal selection study allowed us to acquire knowledge on the behavior of the tested wheat varieties under salt stress conditions However, the germination stage is not sufficient to identify tolerance to salt stress. It is interesting to explore the coping mechanisms involved in the response of these varieties under salinity (including the exploration of other morphological, physiological and biochemical traits) at advanced stages of development and at the cellular level to confirm tolerance/sensitivity during the germination stage. Furthermore, the assessment of combined stresses such as saline and water stress on yield under field conditions is highly recommended.

\section{CONCLUSION}

This study shows the effects of salinity factor applied from washing and disinfection and throughout the germination process on several parameters studied in five varieties of wheat (Amal, Arrehane, Kanz, Radia, and Rajae).

The reported results show that the behavior of wheat varieties during the germination stage is variable. Thus, the parameters studied show that the response of wheat to salt stress varies according to salinity and variety.

It also indicates that the most appropriate criteria for studying the effects of salinity on seed germination are the germination rate, the final germination rate (main descriptor criteria), the reduction percentage in germination, the germination vigor index and the mean daily germination (secondary criteria) Indeed, these parameters varied homogeneously and significantly under the effect of salinity, together with specific reactions that allowed the classification of different varieties. These distinctive criteria have also allowed an identical hierarchy of sensitivity/tolerance levels in the lengthening of the coleoptile and root, which was as well negatively affected by salinity. All these parameters describing the germination of wheat seeds showed that Rajae variety is more efficient (relatively more tolerant) and that the Wissam variety is the most affected by saline stress (sensitive) while Amal and Arrehane varieties oscillate between intermediate positions.

\section{REFERENCES}

Abiala M.A., Abdelrahman M., Burritt D.J., Tran L.S.P (2018). Salt stress tolerance mechanisms and potential applications of legumes for sustainable reclamation of salt-degraded soils. Land Degrad. Dev. 29, 3812-3822. https://doi.org/10.1002/ldr.3095.

Acosta-motos J.R., Penella C., Hernández J.A., Sánchez-blanco M.J., Navarro J.M., Gómez-bellot M.J. (2020). Towards a Sustainable Agriculture: Strategies Involving Phytoprotectants against Salt Stress. Agronomy. 10,194. https://doi.org/10.3390/agronomy10020194.

Afzal, I., A. Butt, H. Rehman, S.M.A. Basra et A. Afzal. (2012). Alleviation of salt stress in fine aromatic rice by seed priming. Australian Journal of Crop Science (6), 1401-1407.

Akbarimoghaddam H., M. Galavi, A. Ghanbari, Panjehkeh N. (2011). Salinity effects on seed germination and seeling growth of bread wheat cultivars. Tarkia Journal of sciences. 9 (1), 43-50.

Almodares, A., M.R. Hadi and B. Dosti. (2007). Effects of salt stress on germination percentage and seedling growth in sweet sorghum cultivars. Journal 
of Biological Sciences

Begum F., I.M. Ahmed, A. Nessa, Sultana W. (2010). The effect of salinity on seed quality of wheat. Agronomy division: Bangladesh Agricultural Research Institute, Joydebpur. 8(1), 19-22. https://doi.org/10.3329/jbau.v8i1.6392

Ben Khaled L., Ouarraqi EM.,Zid E. (2007). Impact du NaCl sur la croissance et la nutrition de la variété de blé dur Massa cultivée en milieu hydroponique, Acta Botanica Gallica, 154(1), 101-116. https://doi.org/10.1080/12538078.2007.10516047.

Ben Miled D, Boussaid M, Cherif A. 1986. Tolérance au sel d'espèces annuelles du genre Medicago au cours de la germination. Colloque sur les végétaux en milieu aride. Tunisie : Djerba.

Ben Naceur M., Rahmoune C., Sdiri H., Meddahi M.L. et Selmi M. (2001). Effet du stress salin sur la germination, la croissance et la production en grains de quelques variétés maghrébines de blé. Sécheresse, 12, 167-174.

Benderraji L., Bouzerzour H., Kellou K., Ykhlef N., Brini F., Masmadi K., DjKoun A. (2010). Etude des mécanismes de tolérance à la salinité chez deux variétés de blé tendre (Triticum aestivum L.) soumises à un stress salin. Sciences et technologie, 23-30.

Berrichi A. Tazi R., Bellirou A., Kouddane N., Bouali A. (2010). Role of salt stress on seed germination and grouwth of jojoba plant simmindsia chinensis link schneider. Journal of biology. 69(1), 33-39.

Bliss R.D., Platt-Aloria K.A. et Thomson W.W. (1986). Osmotic sensitivity in relation to salt sensitivity in germinating barley seeds. Plant Cell and Env. (9), 721-725. https://doi.org/10.1111/i.1365-3040.1986.tb02104.x

Botia P., Carvajal M., Cerda A., Martinez V. (1998). "Response of eight Cucumis melo cultivars to salinity during germination and early vegetative growth". Agronomie 18, 503-513. https://doi.org/10.1051/agro:19980801

Cabello, M.L., Ruiz, T., Devesa, J.A. (1998). Ensayos de germinación enendemismos ibéricos. Acta Botanica Malacitana 23, 59-69

Colmer TD., Munns R., Flowers TJ. 2005. Improving salt tolerance of wheat and barley: future prospects. Australian Journal of Experimental Agriculture (45), 1425-1443.

Czabator F.J. (1962). Germination value: an index combining speed and completeness of pine seed germination. Forest Science 8, 386-396.

D.P.A.E. (2008). Résultat de la récolte des quatre principales céréales : Blé dur, Blé tendre, Orge et Maïs, campagne agricole 2007-2008. Ministre de l'Agriculture et la Pêche Maritime. Proceedings 7ème congrès de l'AMPP. Vol I. Rabat, 26-27 Mai 2010, 175.

El Goumi Y., Fakiri M., Lamsaouri O., Benchekroun M. (2014). Salt stress effect on seed germination and some physiological traits in three Moroccan barley (Hordeum vulgare L.) cultivars. J. Mater. Environ. Sci. 5 (2), 625-632.

Elouaer, M.A. and Hannachi C. (2012). Seed priming to improve germination and seedling growth of safflower (Carthamus tinctorius) under salt stress. EurAsian Journal of BioSciences https://doi.org/10.5053/ejobios.2012.6.0.9

Eskandari H., Kazemi K. (2011). Germination and seedling properties of different wheat cultivars under salinity conditions. Notudae Scientia biological. 3(3), 130-134. https://doi.org/10.15835/nsb336118

Gomes F.E., Prisco J.T., Campos F.A.P. \& Filho E.J. (1983). Effects of $\mathrm{NaCl}$ salinity in vivo and in vitro ribonuclease activity of Vigna unguiculata cotyledons during germination. Plant Physiol. 59, 183-188. https://doi.org/10.1111/j.13993054.1983.tb00755.x

Groome M.C., Axler S., Gfford D.J. (1991). Hydrolysis of lipid and protein reserves in lobolly pine seeds in relation to protein electrophoretic patterns following imbibitions. Physiology of Plant. 99-106. https://doi.org/10.1034/j.1399-3054.1991.830115.x

Hussain S., Khaliq A., Matloob A., Wahid A.M., Afzal Ifran. (2013) Germination and growth response of three wheat cultivars to $\mathrm{NaCl}$ salinity. Soil environ. 32(1), 36-43.

Iraida A., Miguel A.B., Mercedes C., Maria I.M., Antonio H., Ray A.B., Paul M.H., Miguel A.Q. \& Victoriano V. (1999). Improved germination under osmotic stress of tobacco plants overexpressing a cell wall peroxidase. FEBS Letters, 457, 80-84. https://doi.org/10.1016/s0014-5793(99)01011-x

Ismail S., Rao N.K., Dagar J.C. (2019). Research Developments in Saline Agriculture. Springer; Berlin, Germany. Identification, Evaluation, and Domestication of Alternative Crops for Saline Environments,. 505-536.

Jain N. K. et Saha J. R. (1971). Effect of storage length on seed germination in jute (Corchorus spp.). Agron. J. 63, 636-638.

Jorenush Mohammad Hadi, Rajabi Mohsen. (2015). Effect of Drought and Salinity Tensions on Germination and Seedling Growth of Artichoke (Cynara Scolymus L.). Int. J. Adv. Biol. Biom. Res. 3(3), 297-302.

Khemiri H., Belguith H., Jridi T., Ben El Arbi M. \& Ben Hamida J. (2004) Caractérisation biochimique d'une amylase active au cours du processus germinatif des graines de colza (Brassica napus L.). Congrès International de Biochimie. Marrakech 3-6 mai 2004. Enzymologie et métabolisme: 146-149.

Kotowski F., 1926. Temperature relations to germination of vegetable seed. Proceedings of the American Society for Horticultural Science 23, 176-184. https://doi.org/10.2134/agronj1971.00021962006300040037x

Koutoua A., Hmouni D., ElYacoubi H., Hassikou R., Zidane L., Rochdi A (2012). Sélection et évaluation in vitro de lignées de cals tolérants à la salinité chez le blé dur (Triticum durum Desf.). ScienceLib Editions Mersenne, 4, 120708 .

Kumar A., Kumar A., Mann A., Devi G., Sharma H., Singh R., Sanwal S.K. ( 2019). Ecophysiology, Abiotic Stress Responses and Utilization of Halophytes Phytoamelioration of the Salt-Affected Soils Through Halophytes; Springer, 313-326.

Lachhab I., Louahlia S., Laamarti M., and Hammani K. (2013). Effet d'un stress salin sur la germination et l'activité enzymatique chez deux génotypes de Medicago sativa. International Journal of Innovation and Applied Studies. 3, 2, 511-516.

Maghsoudi-Moudi A., Maghsoudi K. (2008). Salt stress effects on respiration and growth of germinated seeds of different wheat cultivars. W J Agric Sci 4(3), 351358 .

Mbarki S., Cerdà A., Zivcak M., Brestic M., Rabhi M., Mezni M., Jedidi N., Abdelly C., Pascual J.A. (2018). Alfalfa crops amended with MSW compost can compensate the effect of salty water irrigation depending on the soil $\begin{array}{llll}\text { texture. Process. } & \text { Saf. } & \text { Environ. } & \text { Prot. }\end{array}$ https://doi.org/10.1016/j.psep.2017.09.001.

Mehmat, A., Kaya M.D., and Kaya G. (2006). Effects of $\mathrm{NaCl}$ on the germination, seedling growth and water uptake of triticale. Turkish Journal of Agriculture and Forestry 30, 39-47.

Mehmet A., Cengiz E., et Sadik Ç. (2013). Comparison of germination and early seedling growth of silage maize (Zea mays L.) exposed to different $\mathrm{NaCl}$ levels. Journal of Food, Agriculture \& Environment, 11(3\&4), 745- 747.

Mirza, H., Kamrun, N., Masayuki, F., Hirosuke, O., Islam, T.M., Shahzad, B., Fahad, S., Tanveer, M., Saud, S., Khan, I.A. (2019). Plant Responses and Tolerance to Salt Stress. In Approaches for Enhancing Abiotic Stress Tolerance in Plants; CRC Press: Boca Raton, FL, USA. pp. 61-78.

Mirzaei A., Naseri R., Emami T., Zozeyan A. (2012). Effect of salinity on germination and seeling grouth of bread wheat (triticum aestivum L.) International journal of agriculture and crop sciences, 4(15), 1089-1091.

Mrani Alaoui M., Eljourmi L., Ourzane A., Lazar S., El Antari S., Zahouily M., Hmyene A. (2013). Effet du stress salin sur la germination et la croissance de six variètès marocaines de blé (Effect of salt stress on germination and growth of six Moroccan wheat varieties). J. Mater. Environ. Sci. 4(6), 997-1004.

Nassif F., Laâmari A1., Boujnah M. (2012). Importance de la culture du blé dur et évaluation différenciée de dix variétés de blé dur dans la région Chaouia au Maroc. Al Awamia (23), 125-126

Natasha K. (2019). Effect of sodium chloride, potassium chloride on germination and growth of Foxtail millet (Setaria italica L.) Pure Appl. Biol., 8,1398-1407. https://doi.org/10.19045/bspab.2019.80080.

Öner Fatih, Kirli Ayșegül. (2018). Effects of salt stress on germination and seedling growth of different bread wheat (Triticum aestivum L.) cultivars. Akademik Ziraat Dergisi, 7(2):191-196.

Ouhaddach M., El yacoubi H., Douaik A., Hmouni D., Rochdi A. (2016) Physiological and Biochemical Responses to Salt Stress in Wheat (Triticum aestivum L.) at the elongation stage. J. Mater. Environ. Sci. 7(9), 3084-3099.

Pendergast JF et Littell RC. (1988). Repeated measures analysis in the SAS system. SAS conference proceedings: SAS users Group International 13 (SUGI 13), March 27-30, Orlando, FL, USA

Prado F.E., Boero C., Gallardo M., Gonzalez J.A. (2000). "Effect of $\mathrm{NaCl}$ on germination, growth and soluble sugar content in Chenopodium quinoa Willd. Seeds”. Botanical Bulletin of Academia Sinica (41), 27-34.

Saboora A., and KiarostamiK. (2006). Salinity tolerance of wheat genotype at germination and early seedling growth. Pakistan Journal of Biological Sciences 9, 2009-2021. https://doi.org/10.3923/pjbs.2006.2009.2021

Safdar H., Amin A., Shafiq Y., Ali A., Yasin R. (2019) A review: Impact of salinity on plant growth. Nat. Sci. 17, 34-40. https://doi.org/10.7537/marsnsj170119.06

Scott SJ., Jones RA., Williams WA. (1984). Review of data analysis methods for $\begin{array}{lllll}\text { seed germination. Crop Sci. } & \text { 24, } & 1192-1199\end{array}$ https://doi.org/10.2135/cropsci1984.0011183x002400060043x

Slama A.D., Afifi W.M., Mousa A.Z. \& Shams El Din. (1992). Biochemical study on the effect of salinity on cucumber seedlings. Annals Agric. Sci. Ain Shams Univ. Cairo, 37 (2), 339-349.

Srivastava N. (2020). Environmental Concerns and Sustainable Development. Springer; Singapore: 2020. Reclamation of Saline and Sodic Soil through Phytoremediation, 279-306.

Bhutto TA., Gula AQ; Bhutto MH., Safdar AW, Mahmooda B, Niaz AW. (2018). Evaluation of wheat varieties to salt stress $(\mathrm{NaCl})$ for seed germination and early seedling growth under laboratoryconditions. Pure Appl. Biol. http://dx.doi.org/10.19045/bspab.2018.700223

Zar JH. (1999). Biostatistical analysis, 4ème édition. [in] : Prentice Hall: Upper Saddle River, NY, USA.

Zhang, J. L., Shi, H. (2013). Physiological and molecular mechanisms of plant salt tolerance. Photosyn. Res. 115, 1-22. http://dx.doi.org/10.1007/s11120-0139813-6

Yan-Nong Cui, Xiao-Ting Li, Jian-Zhen Yuan, Fang-Zhen Wang, Huan Guo, Zeng-Run Xia, Suo-Min Wang and Qing Ma. (2020). Chloride is beneficial for growth of the xerophyte Pugionium cornutum by enhancing osmotic adjustment 
capacity under salt and drought stresses. Journal of Experimental Botany, 71(14),

4215-4231. http://dx.doi.org/10.10.1093/jxb/eraa158

(Anonymous 1) http://www.agri-mag.com/2017/06/ble-tendre-en-bour/

(Anonymous

https://www.inra.org.ma/sites/default/files/publications/ouvrages/varietes.pd

$\underline{\mathbf{f}}$

(Anonymous 3) https://www.fabinet.up.ac.za/index.php/germination-tests 